\title{
Human factors approaches to evaluating outpatient parenteral antimicrobial therapy services: a systematic review.
}

BUGEJA, S.J., STEWART, D., STRATH, A. and VOSPER, $H$. 


\title{
Human Factors Approaches to Evaluating Outpatient Parenteral Antimicrobial Therapy Services: A Systematic Review
}

Sara Jo Bugeja, Derek Stewart, Alison Strath, Helen Vosper

\begin{abstract}
Background: The expansion in terms of available treatment options and models of care has led to a growing global momentum for outpatient antimicrobial therapy (OPAT) services. A systematic review was undertaken to explore Human Factors aspects relating to OPAT service delivery and to evaluate whether OPAT is amenable to description using the Systems Engineering Initiative for Patient Safety (SEIPS 2.0) model.

Method: Following a preliminary search, a search string was applied to four databases, including Medline, Cumulative Index of Nursing and Allied Health Literature, International Pharmaceutical Abstracts and PsychINFO. Inclusion criteria ensured only articles published after the year 2000 and written in English were accepted. The methodological quality of studies was assessed by three reviewers. Narrative synthesis was performed to uncover the key interactions between work system entities which underpin OPAT processes and outcomes as described using the SEIPS 2.0 model.
\end{abstract}

Results: A total of twenty-seven studies were deemed eligible for the final review. Of these, most described sample populations representative of the population under study, while duration of the studies varied from a few months to years. Some studies evaluated a single model of care whilst others evaluated all three currently available models. The breadth and scope of the studies included enabled extraction of rich Human Factors data describing barriers and enablers to service provision.

Conclusion: OPAT is a service which offers significant benefits to both patients and care providers. These benefits include patient satisfaction and wellbeing, as well as financial performance. OPAT is a 
complex sociotechnical system, and a systems approach may offer the opportunity to enhance system design, maximising system performance. This review demonstrates that the service can be better understood using the SEIPS 2.0 model to identify key work system interactions that support performance.

Keywords: OPAT, Human Factors, SEIPS model, Service delivery 


\section{INTRODUCTION}

Performance evaluation of healthcare services is essential in determining whether the anticipated outcomes in terms of patient safety, clinical care and supporting processes (including financial viability) are being met. Currently, it is typically assessed using key performance indicators such as bed turnover and occupancy rates, average length of stay, and hospital infection rate ${ }^{1}$. A pragmatic way of positively influencing these indicators is to discharge those patients who are otherwise stable, and are in hospital solely for the purpose of receiving intravenous antimicrobials, to a home setting where they can receive outpatient parenteral antimicrobial therapy (OPAT). OPAT is defined as "the administration of at least two doses of parenteral antimicrobial therapy on different days without intervening hospitalization"2. Initially developed in 1974 by Rucker and Harrison for treating a paediatric population ${ }^{3}$, OPAT has evolved into a dynamic and complex service used worldwide for the treatment of infections that require prolonged use of intravenously administered antibiotics in patients who are otherwise clinically stable and willing to continue their treatment as outpatients ${ }^{4,5}$. This evolution has given rise to three complex models of care, which include the home (which may involve either a visit from a healthcare professional, but also includes self-administration), infusion centres and skilled nursing facility-based care environments. Each setting is therefore governed by individual and potentially diverse procedures, showing considerable variability in terms of patient/healthcare professional interaction, and having unique safety concerns as well as other differences ${ }^{2,6}$.

A discipline gaining an evidence-based reputation for addressing healthcare complexity is systems thinking, which is at the core of Human Factors research and practice ${ }^{7,8}$. Human Factors (also known as Ergonomics) is "a discipline which strives to understand the interactions between humans and other elements of a system. It is also a profession that applies theoretical principles, data and methods in practice, supporting the intelligent re-design of systems in a way that optimises both human wellbeing and overall performance"' . The compelling argument for its integration in national health services and policy is due to the often competing needs for ensuring sustainable patient safety procedures ${ }^{8,9}$ as well as the delivery of other desirable outcomes such as financial performance ${ }^{10}$. The systems engineering 
initiative for patient safety (SEIPS) model was designed in 2006 by Carayon et al. to provide a usable Human Factors framework for application in healthcare systems ${ }^{15}$. Since then, it has been applied in a range of diverse settings. Furthermore, the model has evolved, with SEIPS 2.0 incorporating developments that are particularly valuable in addressing contemporary healthcare needs. The global response to the 'safety crisis' (first recognised in the Institute of Medicine report 'To err is human') ${ }^{11}$ has been to attempt to reduce errors, reduce patient injury and to adopt an evidence-based approach to treatment ${ }^{12}$. All these approaches emphasize that 'system design' is the key to such reductionist strategies. However, there is very little in the way of meaningful advice to support such re-design, reflecting a lack of understanding of the mechanisms that link system design to outcomes. This almost certainly results from an excessive focus on outcomes (and patient outcomes at that). Genuine Human Factors approaches are based on the understanding that outcomes are generated as a result of interactions between work system entities and that these interactions are driven by human work processes. In complex sociotechnical systems, the interactions are so many and often so unpredictable that the outcomes themselves can be hard to understand, a concept known as 'emergence.' While outcomes are ultimately what matters, they are difficult to influence positively without a deep understanding of system interactions that produced them. Human Factors approaches recognize that outcomes are influenced by human performance and that effective design can both support this performance as well as reducing hazards that threaten good performance. The interactions between the work system entities can be viewed as 'inputs' which are 'transformed' by human performance to yield outputs (including those related to safety). SEIPS $2.0^{13}$ focusses on these transformations, dividing them by type (physical, cognitive and/or social/behavioural) and in terms of the interactions of the people within the system (these are divided into 'professional-only', 'patient-only' and 'patient/professional collaborative work'). The 'work system' element of the model supports exploration of how interactions between entities support human performance. The model also facilitates a macro-level consideration of the larger system, but also offers insight into the nested systems and multiple organizational layers within. Systems vary in size, and large systems are invariably made up of smaller systems. Such 
'nesting' can be observed within the OPAT service: a nurse administering the patient's treatment (micro), the OPAT team (meso) or the OPAT service as a whole (macro). This can also be seen in cross level interactions whereby for example the healthcare professional is at the frontline carrying out the tasks (micro) in response to a decision-making process which defines how the service will be offered (macro). A final consideration is the level of interaction occurring between macro and micro though cross level bridges (for example, communication is of critical importance at all levels ${ }^{13-15}$.

To date, SEIPS 2.0 has not been used to explore OPAT, which can be considered a complex sociotechnical system due to the high frequency and relative unpredictability of the interactions occurring between its entities. These entities include the people (e.g. patients, carers and healthcare professionals) and their environment, the organization responsible for the delivery of the service, the component tasks and the tools and technologies that support delivery. The patient (and carers) play an unusual role within the OPAT system, and the division of 'transformations' into 'patient', 'patientprofessional' and 'professional' may be particularly useful.

The aims of this systematic review were (i) to critically appraise, synthesize and present the available evidence relating to adult OPAT services and (ii) to explore if the OPAT service is amenable to analysis using the SEIPS 2.0 framework.

To achieve these aims, two review questions were designed in relation to the amenability of the OPAT service to analysis using the SEIPS 2.0 model. The first question focused on the identification of systems factors, in terms of the SEIPS 2.0 framework which have been reported in service development, implementation and evaluation. The second question concentrated on the general outcomes of OPAT in terms of service development, implementation and evaluation.

\section{METHOD}




\section{Protocol Development}

The systematic literature review protocol was designed using the guidance offered by the PRISMA-P (Preferred Reporting Items for Systematic Review and Meta-Analysis) statement ${ }^{16}$ and submitted to The International Prospective Register of Systematic Reviews (Prospero) for consideration and registration ${ }^{17}$.

\section{Inclusion/ Exclusion Criteria}

\section{Population}

Patients, carers, policy makers, nurses, pharmacists, infectious diseases physicians named as stakeholders and involved in any stage of adult OPAT service development were included. Data were evaluated and implemented even if there was no specific mention of Human Factors. Data from studies relevant solely to paediatric populations were not included.

\section{Types of interventions}

Studies which reported any intervention occurring in the context of an OPAT service development. Articles describing implementation and evaluation were included.

\section{Type of Comparators}

Not applicable.

\section{Outcomes}

Studies which reported outcome measures of an OPAT service including (among others) the number of patients enrolled, adverse reactions, readmissions and treatment success.

\section{Study design}


No studies were omitted on the basis of study design. Studies applying qualitative (e.g. randomized controlled trials, observational design etc.) or mixed methods were included. Peer-reviewed primary research studies, systematic reviews and meta-analyses were included. Abstracts, letters and grey literature were not included.

\section{Language}

Only studies published in English were included.

\section{Capture dates}

Studies published from January 2000 up to June 2019 were included, as this captured the time period during which the application of theoretical principles of Human Factors had gained importance in the patient safety literature. Although healthcare Human Factors literature exists prior to this date, it almost entirely focusses on staff safety, such as safe handling of patients.

\section{Search strategy}

A three-step search strategy was utilized in this review, beginning with an initial scoping search of Medline and Cumulative Index to Nursing and Allied Health Literature (CINAHL) using search terms [(“outpatient parenteral antimicrobial therapy" OR "outpatient parenteral antibiotic therapy" OR “OPAT") AND ("human factor" OR "ergonomic" OR "adaptation"]. Note was taken of terms present in the titles, abstracts, keyword section and references to formulate the search string. This search string incorporated the Boolean operator "OR" for the sub-terms for each core term (namely Human Factors, Antibiotics, OPAT and Administration) and these searches were amalgamated together using the Boolean operator "AND" to create the final search string (Table 1).

\section{[Table 1]}

The search string was then applied to four principal databases, namely MEDLINE, CINAHL, International Pharmaceutical Abstracts and PsychINFO and the results were recorded. Criteria such as 
the capture dates and language preference were inserted prior to running the search. Finally, the reference lists of the 121 papers identified were further reviewed.

\section{Screening and selection}

Titles, abstracts and descriptions of all studies identified during the database search were assessed for relevance to the review by two independent reviewers.

\section{Data Extraction}

Multiple reference tools were used to construct the data collection tool. These included The Joanna Briggs Institute data extraction form for experimental/observational studies ${ }^{18}$, the Systematic Reviews Centre for Reviews and Dissemination (CRD) guidance for undertaking reviews in health care $^{19}$, the Cochrane public health group and the Cochrane guidance on extracting qualitative evidence. ${ }^{20}$ The resultant tool captured general information about each study, including author and setting, participants, intervention, outcomes and system factors as described within the SEIPS 2.0 framework. It is important to note that almost none of the articles made specific reference to Human Factors and thus extraction almost entirely depended on the subjective opinion of the reviewers concerned. The Risk of Bias in Systematic Reviews (ROBIS) tool was used to ensure that the risk of bias was kept as low as possible ${ }^{21}$.

The SEIPS 2.0 model was utilized to categorize the systems factors, interactions and transformations (work processes) as described within the articles and, because of the subjective nature of the process, the final categorization was evaluated by all reviewers. Any conflicts were discussed to allow consensus to be reached.

\section{Quality Assessment}


All studies were assessed for methodological quality by two independent reviewers. Standardized critical appraisal instruments were used and adapted to suit the needs of the articles chosen. The Critical Appraisal Skills Programme (CASP) tools, as well as those described by Young and Solomon ${ }^{22,23}$ were modified to create the final quality assessment tool which covered subjects such as the articles' objectives, design, recruitment and data collection strategies, ethics, results, biases and Human Factors aspects which could be identified from the reported data. With respect to Human Factors, the reviewers also assessed whether entities and interactions could be categorized using the SEIPS 2.0 framework. Reviewers rated each question by giving the following answers Yes, No, Unclear, Not applicable or Partial.

\section{Data Synthesis}

The first step was to define the system entities and categorize the factors considered to relate to these entities. The next stage was to identify work processes and categorize these according to SEIPS 2.0 definitions. The final step was to identify interactions between the work system factors that had the potential to influence work processes and therefore outcomes. As with any complex system, OPAT factors were frequently assigned to more than one category. For example, the work system component 'person' could refer to the patient receiving the service. In this case, one 'person factor' would be the relationship between a patient's disease state and the suitability of the treatment selected. Similarly, the choice of antibiotic was considered to relate to 'task' (selecting the antibiotic), 'person' (having the skills and knowledge required to make this choice) and 'tools and technology' (the antibiotic itself) factors. Another example was the enforcement of standardized criteria which could be considered as an 'organizational', 'person', 'tool' and 'internal environment' factor due to local need to enforce policies, patient eligibility in relation to these criteria and whether or not the (patient's) residence meets the requirements as described in the criteria respectively. These steps are illustrated in Figure 1 below.

\section{[Figure 1]}




\section{Results}

[Figure 2]

\section{Searching}

The PRISMA chart in Figure 2 illustrates the results of each phase of the literature search. Of the 189 articles initially identified, 179 were drawn from the four main databases whilst 10 were identified from article references. Of these, 29 were duplicates and 122 did not meet the inclusion/exclusion criteria. 38 full text articles were assessed. 11 full text articles were removed because of a lack of relevance, leaving a total of 27 for final review. Critical appraisal and data extraction were carried out for each of these articles.

The number of participants was generally constrained by the study time frame or the setting chosen by the authors. For example, in the study published by Htin et al. despite the study period running from June 2002 to July 2011, because only patients diagnosed with infective endocarditis were considered for inclusion, the sample size was only 68 patients. ${ }^{36}$ This contrasts with the study carried out by Barr and colleagues which covered a similar timeframe (January 2001 to December 2010), but included patients with a variety of disease conditions, and therefore involved a total of 2233 patients ${ }^{37}$.

It is worth noting that, when reported, specified inclusion criteria reflected patient eligibility as articulated in guidelines, suggesting attempts to achieve a high standard of practice ${ }^{2}$. These inclusion criteria included clinical stability ${ }^{29,33,49}$, lack of psychiatric disorders ${ }^{29}$, no history of drug abuse ${ }^{49}$, the presence of family support ${ }^{29}$, home telephone and transport facilities ${ }^{29,33,49}$, completion by the patient of at least two days of OPAT delivery in the infectious disease clinic $^{32}$ and consultation with an infectious disease physician prior to engaging with the OPAT service ${ }^{27}$. Details of the study characteristics can be found in Table 2.

\section{[Table 2]}




\section{Quality Assessment}

As can be seen from Figure 3, most publications were able to satisfy the questions designed to assess quality. Positive responses are indicative of high quality for that aspect of the reported research. Moreover, an almost complete consensus was attained amongst the three reviewers. The question attaining the highest number of positive answers referred to the identification of aspects of the system which could be considered classifiable from a SEIPS 2.0 perspective $(27 / 27 ; 100 \%)$. The question relating to clarity of the findings gained 26/27 (96\%) positive responses, while almost all studies (25/27; 93\%) were considered to have fully described their participant characteristics, collected data in an appropriate manner and to have clearly stated their findings in relation to the aims. The 'not applicable' option was only used once by the reviewers for the ten questions posed. Moreover, for those publications which lagged in terms of positive responses, there was a high proportion of partial rankings, especially in items relating to the research design and declaration of conflicts and bias. Overall, the quality of the included studies was considered high.

[Figure 3]

\section{Data Extraction and Synthesis based on SEIPS mapping}

\section{Outcomes}

\section{[Table 3]}

Most studies stated evaluation of the service as an aim, despite variability in the outcome measures chosen as performance indicators. Such indicators included safety and efficacy $24,32,29,34,36,30,25$, frequency of readmission ${ }^{27}$, presence/absence of certain care processes ${ }^{39,49,27,35,48,47}$, quality of life ${ }^{31}$, patient satisfaction ${ }^{45,46,33,50}$, cost effectiveness ${ }^{24,33,38,50}$, treatment completion rates $^{38}$, failure ${ }^{28,40,41,42}$ and 
expansion of the service ${ }^{37,43,44}$. Due to the heterogeneity in terms of aims, settings and populations, the results described by the authors varied in terms of their reported outcomes (see Table 3). Some studies reported the rate of readmission, success, death and complications as described in Table 4.

\section{[Table 4]}

Also of interest is the range of healthcare professionals mentioned in the studies. One study described a team comprising physicians, nurses, a social worker and pharmacist ${ }^{39}$, others made reference to physicians, nurses and pharmacists $27,31,37,41,43,49$ whilst some referred to a team composed of doctors and nurses only ${ }^{24,48,35,38,32,29,36}$. Some papers merely referred s to an 'OPAT team', making it very difficult to identify precisely those healthcare professionals involved in the service delivery. A few studies referred to other stakeholders, including the family physician ${ }^{33,50}$, nurse care manager ${ }^{39}$, medication courier $^{26}$, community nursing personnel ${ }^{31,26}$ and the clinical microbiologist ${ }^{49}$. There was also the occasional mention of carers and their role in the delivery of the service. This largely referred to the importance of their receiving education about the service and skills needed to administer treatment ${ }^{37,49}$.

\section{Processes}

A series of common processes are inherent in any OPAT service irrespective of the model of delivery practised and the presence or absence of a formal OPAT programme ${ }^{34,43}$. The following sections highlight the professional work, patient work and the 'collaborative work' making up the work processes in terms of their physical, cognitive and social/behavioural elements as described by Karsh et al., ${ }^{12}$ Carayon et al. ${ }^{15}$ and Holden et $a .^{13}$. Despite the broad spectrum of services offered, some processes were common to all studies. The first of these was patient selection, a process composed of a collection of tasks designed to determine the suitability of the patient as an OPAT candidate. These tasks include reviewing the patient history to assess the impact of comorbidities, and assessing the 
potential impact of other constraints such as the suitability of the home environment as well as the physical capabilities of the patient, including - for example - their mobility etc. The eligibility of the patient is assessed in relation to both the model of care selected for that patient and what can reasonably be provided by the service provider. Once the referral to the OPAT team takes place, a treatment plan is devised with the plan including administration guidance. The involvement or otherwise of a formal OPAT team and/or an infectious disease physician depends on the specific setting. Collectively, completion of these tasks leads to the critical process of discharge of the patient from the hospital onto the service, which involves the patient crossing a service boundary. Once discharge to the service is complete, subsequent processes relate to the administration of treatment, taking blood samples and monitoring laboratory parameters to ensure safety and efficacy. The latter processes, together with those related to follow up (be it during a virtual ward round or a patient-doctor visit at the hospital) form a continuous cycle which is only broken when the patient is deemed fit to be discharged from the service. From the moment the patient is approached by a member of the OPAT team for enrolment in the service until the point of discharge, most of these processes represent collaborative work. Processes which describe purely professional work include the evaluation of a patient's eligibility to enter the service, the monitoring of laboratory results and follow-up procedures. The main processes are depicted in Figure 4.

[Figure 4]

\section{Professional Work}

[Table 5]

\section{Collaborative Work}

[Table 6]

\section{Patient Work}




\section{[Table 7]}

Despite the lack of Human Factors reporting, extraction of factors relating to the OPAT work systems as described in the 27 articles was undertaken and the results presented in Table 8 .

\section{[Table 8]}

In Table 9, the most frequently reported key interactions between these factors are highlighted

\section{[Table 9]}

\section{Discussion}

The papers identified covered a range of OPAT models, disease conditions, age groups and country settings which effectively supported a partial SEIPS mapping, yielding valuable information to support practitioners involved in the design and delivery of OPAT services. This value was further reinforced by the high methodological quality of the papers selected for the review. Perhaps unsurprisingly, given the relative infancy of the discipline in healthcare, almost no direct mention of the term 'Human Factors' was made in the studies reviewed. An exception to this was the work of Keller and colleagues ${ }^{25,26}$. These articles specifically mention the term, and their work describes a task analysis approach to risk management in OPAT delivery. These authors refer to the SEIPS model, but while this has been used as a framework to support the development of tools to explore aspects of the OPAT system, they do not present a complete SEIPS analysis. We believe that this current work is unique in terms of describing the OPAT service through a SEIPS 2.0 lens, suggesting the service is amenable to mapping in this way.

\section{Processes}

Processes which involved Professional Work 
Patient selection appeared to be the most important cognitive process carried out by professionals within the OPAT service context. In fact, three out of six processes reported by Gilchrist et al, specifically focused on this aspect, including the patient's eligibility, their acceptance on to the service and assessment by the team ${ }^{28}$. Based on the outcomes of an assessment of the patient's mobility and capability for self-administration, a healthcare professional must decide on the most suitable OPAT model. This cognitive process - involving knowledge, forethought and problem solving - was reflected in an apparent decision to avoid certain patient cohorts reflecting an desire to achieve high success rates with few adverse events, which is a behavioral process ${ }^{32,36,37,40}$.

The most frequently reported physical process carried out by professionals was the administration of antimicrobial agents. The ability of professionals to access patients across a range of physical environments depending on the model of delivery ${ }^{38,44}$ (a physical process) alongside their having the necessary skills to administer medication via a variety of vascular access devices (e.g. peripherally inserted central catheter; PICC) ${ }^{44,48,45}$ could together be seen to enhance the overall culture of service provision (a behavioural process). In a scenario where a patient is difficult to reach daily (a physical process), the ability of the professional to teach the patient self-administering techniques (a cognitive process) is an important part of empowering patients to start managing their own condition (a social/behavioral process) and overcome the constraints imposed by geographical location ${ }^{37,48}$.

Requesting (and charting the results of) laboratory monitoring of patients was seen to be an important physical process as it contributed directly to healthcare professionals' informed decision-making in

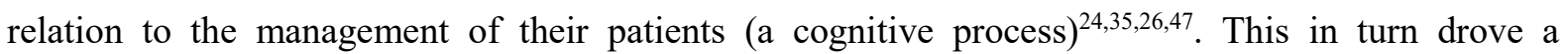
social/behavioral process which ensured that the need for a systematic method of accessibility to laboratory results was highlighted, ${ }^{43}$. It could also be seen that continued laboratory monitoring assisted OPAT directors in monitoring readmission rates $^{34,43,30}$ and ensuring clinical governance related to OPAT is maintained ${ }^{37}$. 


\section{Processes which involved Collaborative Work}

The availability of a telephone OPAT helpline supported the physical aspect of the communication process, which is essential for both the answering of patient queries and for the monitoring of patients by healthcare professionals $\mathrm{s}^{36,46,45,26}$. This communication, in turn, supported the cognitive process of validating the original decision made between these stakeholders to enter the OPAT service. Moreover, professionals could be seen to take person factors such as patient age, dexterity, co-morbidities and presenting infections into consideration (a cognitive process). This aspect promoted the social/behavioral aspect of communication between stakeholders thus supporting better overall outcomes ${ }^{28,49,26}$.

Other physical processes involved the professionals' visits to patient residences and patients' visits to the hospital (or centre offering the service) ${ }^{34}$, getting patients' consent and endorsement prior to prescribing toxic treatment, ${ }^{34}$ the reporting of adverse events ${ }^{35}$, removal of the vascular access device ${ }^{26}$ and the decluttering of the residence prior to a home visit ${ }^{(46)}$.

\section{Processes which involved Patient Work}

As with the professional group, 'treatment administration' also appeared as a 'patient only' process as part of the self-administration mode (with or without the assistance of family members or carers) ) $^{39,30}$. Patients were taught the necessary skills to perform administration in their home environment ${ }^{37,44,45,30}$ (a cognitive process). Its success in turn empowered patients, promoting a positive culture favouring OPAT admissions driven by the patients' positive attitudes ${ }^{33,49}$ (a social process).

Certain physical processes were attributed to specific cohorts. For example, geriatric patients were seen to present at the emergency department or to telephone OPAT team members for assistance more frequently ${ }^{39}$. This proved to be beneficial in that it appeared to help reduce worsening mental function 
${ }^{29}$ (cognitive) and encouraged patients of this age group to accept admission to the service by ensuring family support, comfort in their home environment etc. ${ }^{29}$ (social). Another 'stand out' cohort were intravenous drug abusers who frequently failed to attend follow ups and often misused intravenous devices which made them non-adherent to therapy (cognitive) leading to failed OPAT courses ${ }^{43}$ (social).

\section{Systems Factors as described by the SEIPS 2.0 Model}

Through the SEIPS 2.0 lens, the OPAT service is viewed as a dynamic work system whose outcomes are the result of processes which, in turn, are underpinned by interactions occurring between various system entities. Using the example of administering treatment, it could be seen that a number of 'task factors' strongly interact with 'tools and technologies factors' which in turn interact strongly with 'person factors' such as training and expertise in relation to these tasks. These interactions could be seen to impact on the success or otherwise of processes in delivering outcomes.

\section{Task Factors}

With respect to the tasks described in the provision of the service, emphasis was placed on the enforcement of standardized patient selection criteria following individual assessment, and many studies strongly attribute the success rate of the service to this task ${ }^{32,29,35,36,38,53}$. Studies also mentioned that improvements to the care process could be driven by an organizational strategy that supports the implementation of standardized channels for communication such as an electronic database, a tool/technology accessible to all, which can effectively support multidisciplinary meetings ${ }^{47,43}$. The database was also seen to reduce the risk of erroneous antimicrobial prescribing going unnoticed and to allow close monitoring of blood laboratory results as well as supporting patient follow up ${ }^{32,27,34,37,41}$.

In the study published by Miron-Rubio et al., the efficiency of the healthcare professional was mentioned when referring to the ability to successfully administer more than one antibiotic during the same visit ${ }^{48}$. This is an example of a key interaction between a task factor and a person factor. 
Furthermore, Lane et al. went on to suggest that such tasks are additionally complicated by the external environment. For example, increased geographical reach of the service would put further strain on the work system ${ }^{35}$. This would in turn influence the administration times - especially in the nurse 'outreach at home' model - and thus impact the overall efficiency of the service ${ }^{49}$. This key interaction warrants further research as it is inherent in all OPAT services.

One problem noted in several studies was catheter complications, with better education for both the healthcare professional and the patient (especially in a self-administration model) considered key to reducing their incidence ${ }^{27,38,26,25}$. Education and the need to take an interest was also stressed not only in terms of the patients, but also for informal caregivers who may be supporting a patient with a high medication burden due to other comorbidities ${ }^{29}$. Self-administration introduces different risks into the OPAT service, and education is therefore considered an important element of risk management in this group $^{48}$. Rather than considering the traditional education approach, a Human Factors response would be to view this as a design problem and perhaps consider the tools/technology element by procuring more efficient and/or usable equipment, such as the use of elastomeric pumps instead of the gravity method of administration. Indeed, the SEIPS 2.0 model highlighted the fact that extent of training/education was not the only factor contributing to administration failures, but that the design and usability of the equipment was also an influencing factor.

A geriatric population is a cohort which might be expected to require more assistance from the OPAT team due to the potential for reduced capability, including, manual dexterity, mental capacity, and the need for physical assistance ${ }^{39}$. The issue of patient compliance was tackled both by Hernandez et al. and Williams et al. in terms of e.g. missed appointments ${ }^{38,43}$ as well as non-adherence and misuse of intravenous devices ${ }^{43}$. The patient's level of knowledge and skills to perform certain techniques was deemed important when assessing the success of the service ${ }^{39}$ and, again, the skill level required will very much be affected by usability/design of equipment. Poorly designed equipment exerts high task 
demands on the user, and when user capability is reduced, the mismatch between demand and capability can make poor outcomes much more likely. A failure to consider (and usability test) equipment is a common healthcare failing that can inadvertently exclude certain groups from a service. Groups such as the elderly, with the impact that age inevitably has on capability, are particularly vulnerable.

\section{Person Factors}

The concept of 'person' in the SEIPS 2.0 model identifies a number of individuals involved in the running of the OPAT service. Considering OPAT is based on teamwork, communication and equal contribution leadership model, the need for assigning roles and task responsibilities to all stakeholders (both a task and organizational factor) was deemed crucial, be it led by an OPAT director ${ }^{34}$ or a designated, qualified team ${ }^{27,28,33,35,43,47}$. Given the collaborative nature of much of the work, defining patient and carer roles and responsibilities is equally important. Education was a recurrent theme. Firstly, mention was made of the OPAT providers' ability to act in an educator role, especially in the home model when patients are not in the presence of a healthcare professional all the time, unlike the inpatient setting. This is even more critical in the self-administration model, where the patient must shoulder much of the responsibility in terms of administration, sterility and other aspects. ${ }^{29,39,37,45}$. The need for education was also mentioned in respect of the referring physicians: These have an important role in selecting patients to minimise the likelihood of failures resulting from operational or clinical issues $^{49}$.

Finally, the physician's knowledge and the importance of continuing professional development was highlighted by Williams et al., especially when considering the potential impact this has on their making the correct treatment choice in terms of cost, frequency, administration, presenting and co-concomitant disease among others ${ }^{43}$. The three studies published by Duncan et al., Hitchcock et al. and Seaton et al. looked at the attitude of health professionals and the impact of this on outcomes. A proactive attitude, combined with a high level of knowledge, allowed them to take pre-emptive action to prevent a 
readmission or complication. An example of this includes the decision to switch the patient to oral therapy ${ }^{40,42,49}$. In contrast, Miron-Rubio et al. and Gilchrist et al. suggested that the ability to make a pre-emptive intervention was best supported by standardised monitoring practice combined with appropriate follow-up 28,48 .

Provider satisfaction was highlighted in studies by Al Ansari et al. and Al Alawi et al. as an important outcome which in turn would influence all persons in the work system. It was suggested that the positive reinforcement produced by high satisfaction would further encourage physicians and healthcare institutions to widen their service provisions, such as expanding delivery models to accommodate all three OPAT options (hospital-based infusion centres, nursing outreach programmes to patient residences and self-administration by patient or carer $)^{33,50,44}$.

The need for good communication, as mentioned previously, was considered important. The SEIPS 2.0 model is particularly useful when it comes to considering communication within a system. Communication as an individual skill is undoubtedly a 'person factor' which can impact strongly on outcomes. Communication and non-technical skill development programmes can be useful here. However, complex sociotechnical systems are often not designed in a manner which supports effective communication. In this case, 'communication' can be considered a high-level, emergent outcome. It is important to understand the difference, otherwise communication failures may be responded to by providing healthcare professionals with non-technical skills training. If system design is the problem, this is unlikely to be successful, and possibly disenfranchises those who already have good nontechnical skills. Gilchrist et al. describe the lines of communication that should be established and maintained, suggesting that communication issues within OPAT service delivery are more likely to be outcomes, rather than person factors. Important lines of communication included those between the patient and OPAT providers, OPAT providers and the relevant internal/external departments and the OPAT team members themselves. This study found that $57 \%$ of failures were identified as being related 
to communication issues, which further supports the notion that poor communication is a system failing rather than an individual skill failing ${ }^{28}$.

System factors attributable to patients included their underlying health. Despite the high overall success rates reported in the studies, readmissions were not uncommon, with complications relating to a number of different reasons (including adverse drug events, catheter and line infections) $)^{27}$. Some failures even resulted from the severity of the infection in question rather than any adverse event ${ }^{39}$. The frequency of these complications was further increased in the presence of co-morbidities which negatively influenced the achievement of a level of stability considered sufficient for discharge and treatment success $\mathrm{s}^{29,40,42}$. Compromising infections such as the acquisition of Methicillin-resistant Staphylococcus Aureus (MRSA) were also seen ${ }^{49}$. An example of how these factors might combine could be seen in patients who, due to the presence of comorbidities, require parenteral nutrition. These individuals are at an increased risk of bloodstream infections which, in turn, is a risk factor for catheter related infections ${ }^{39}$. This is an example of an interaction between the task factor of 'patient selection' with the person factor of 'individual patient characteristics' which, in this case, is the type of feeding required by the individual.

Social complications such as a change in the patient's residence ${ }^{32}$ and/or a patient's financial situation ${ }^{38}$ were considered as key elements which could compromise outcomes perhaps, for example, leading to cessation of the programme. The study presented by Perez-Lopez et al. showed that a geriatric population potentially had much to gain from an OPAT service since it gives them the opportunity to retain their residential environment, social interactions and family commitments, physical space, dietary habits etc ${ }^{29}$. Similar findings were reported in the paper published by Williams et al., which suggested there was an increased sense of wellbeing, while Bernard et al. reported that their geriatric cohort were satisfied in terms of the treatment and the ability to maintain a normal schedule ${ }^{24}$. Such groups can often be excluded from the service because of the multiple morbidities likely with older age and also a lack 
of live-in carer support. Careful selection of antimicrobial agent may help - agents that only need to be delivered once per day would keep the care burden to a minimum.

Patient satisfaction was assessed as an outcome in three of the selected studies: Al Alawi et al., who chose the short form patient's satisfaction questionnaire (PSQ-18) ${ }^{51}$, Al Ansari et al. who formulated a questionnaire ${ }^{33}$ and Goodfellow and colleagues who used mental scores as a measure of mental health, and this was seen to link to overall satisfaction. Goodfellow et al. reported positive results in terms of reduced psychological distress and impaired social functioning related to emotional problems. These effects were seen to encourage the use of the service ${ }^{31}$. Satisfaction was also extrapolated using thematic analysis from the interviews performed in the qualitative studies performed by Twiddy et al. and Berrevoets et al., when patients explained that despite their co-morbidities, OPAT had a positive impact on their activities of daily living ${ }^{45,46}$.

\section{Tools and Technology Factors}

The importance of screening for MRSA was highlighted as it was associated with poor outcomes, irrespective of the length of treatment, age and diagnosis, ${ }^{41}$ thus emphasizing the need for advanced laboratory testing for this organism. Lane et al. remarked on the influence of having an adverse event reporting system whilst Durojaiye et al. commented on the importance of an in house database containing details of the patient courses provided by the service. These were dismally absent in most settings and are an important tool to have especially when considering the importance given to feedback as highlighted in the SEIPS 2.0 model $^{35,47}$.

Increased efficiency of service provision was attributed to the enhancement of tools and technologies used for administration, for example, the use of an elastomeric electronic infusion pump ${ }^{48,30}$. Such enhancements theoretically permit a higher patient intake as administration times should be reduced. 
Another example is the availability of technology for performing laboratory testing, which should support better clinical assessment ${ }^{43}$. Moreover, a relationship was highlighted between low adverse event rates and close monitoring of patients, further emphasizing the need for optimal monitoring technologies, especially when the service is being delivered in patients' residences ${ }^{24}$.

Most tools and technology factors related to the patient's residence and the patient's ability to use tools, maintain their sterility and resolve any complications, particularly during self-administration ${ }^{39}$. This aspect was studied in considerable detail by Keller et al. as part of their OPAT hazard identification approach $^{25}$. This is example of another key interaction in the OPAT system, here between a person factor, a technology factor and an environmental factor.

\section{Organization Factors}

The provision of the service on an outpatient basis was seen to deliver positive outcomes for the organization in question, including reduced readmissions and incidence of nosocomial infections $\mathrm{s}^{45,54}$. Moreover, reduced cost burdens were reported, partly due to increased hospital capacity realized as a result of patients being discharged to OPAT, but also due to the reduction in the unnecessary use of medicines that was associated with medicine reconciliation by the OPAT team ${ }^{33,43}$. The organizational crux of the quality of the service was recognized as the 'standard framework', one which encompasses guidelines, articulates and supports standard lines of communication. Other essentials of such a framework were considered to include standard procedures such as obligatory infectious disease consultation with a medical consultant prior to discharge, laboratory monitoring and follow-ups designed to pre-empt complications. The lack of more frequent standard monitoring prevents the early detection of adverse events, making interventions futile or overdue ${ }^{35}$. Also considered to be important was the existence of designated personnel with clearly articulated roles, including the senior management team ${ }^{38,34,43,40}$. Important facets of the service were highlighted, such as the need to address 
patients' co-morbidities (such as achieving better diabetic control, or wound management among others). This was on a par with the need to ensure that patients complete their treatment ${ }^{41}$. Moreover, the provision of treatment at home, was recognised as an added benefit in terms of minimising the spread of certain infections such as Clostridium difficle ${ }^{45}$.

Studies also stressed the need for an organization to adopt specific measurable outcomes to verify the success of the service, including frequencies of complications and clinical cure, patient satisfaction and readmission rates amongst others ${ }^{40}$. Durojaiye et al went a step further by creating a predictive model based on commonly known OPAT variables to avoid unnecessary readmissions ${ }^{54}$. It is considered that this high level of standardization - especially at the pre-discharge OPAT phase - will help the service thrive when faced with an increasingly heterogeneous population making use of it, ${ }^{27,34,35,42}$ especially as the range of anti-microbial agents considered for OPAT use increases ${ }^{37}$. Other organization factors include patient selection. In the process map designed by Gilchrist et al., 31 failure issues were attributed to this very first part of the service, providing further evidence that the eligibility criteria and pre-discharge phases are of extreme importance ${ }^{28}$.

Another important organizational element revealed in the more recent literature is the level of flexibility of the service, notably the ability to adapt to the daily changes in staff workload without allowing this to impact on the patient's daily activities, which several patients described as a drawback of OPAT. Examples of how this might be dealt with include the use of longer acting microbials to reduce the number of visits required at the patient's home and thus increase their overall freedom. This is an example of how an organizational factor (sourcing of medicines) interacts with a tools factor (the dosing regimen of the antibiotic) and with a person factors (staff workload and patient wellbeing $)^{45,46}$.

\section{Environmental Factors}


The OPAT service is influenced by two 'environments', the internal and external which can take the form of recommendations stipulated in guidelines ${ }^{2,30}$ (external) or the actual physical space in which the service is rendered (internal) for example an OPAT clinic $^{30}$, the hospital environment or the patients' residence ${ }^{45}$. Due to the variety of internal environments in which the service can be rendered (depending on model) studies have highlighted the importance of maintaining certain standards within the patient's internal environment. For example, the study by Keller et al. ${ }^{25}$ encouraged avoidance of extreme temperature at the patient's residence to safeguard the integrity of the dressing whilst Voumard et al. commented that such measures will ensure the stability of medicines being administered through elastomeric pumps at home ${ }^{52}$,

\section{Strengths and Limitations}

This systematic review set out to achieve an important goal in terms of understanding the extent to which Human Factors had been considered as an approach in OPAT delivery. Early scoping searches had indicated there was little or no literature to suggest this had been done. Consequently, the scope of the review was increased with the intent to categorize the extracted data using an established Human Factors and Ergonomics framework. Through this systematic review, factors inherent in the work system and influencing measured outcomes could be observed. It is also of interest to notice the level of overlap between the studies in terms of the factors identified. This is important as not all cohorts were the same - some varied in terms of disease condition, age, means testing, country etc., yet the same predominant issues kept resurfacing. Categorising factors according to the SEIPS 2.0 model enables stakeholders to identify generic enablers and barriers, allowing intelligent system re-design to support positive outcomes. All studies suggested patient selection criteria and stakeholder education were particularly important. The ongoing need to focus energy on education and training indicates that the system is not that well designed and thus would potentially benefit from a Human Factors approach. 
Although the systematic review was limited by the exclusion criteria which only reviewed articles in English published after the year 2000, this study was guided by the ROBIS tool and inter-rater reliability assurances were made throughout. Moreover, it is important to note that it is the first of its kind, one which uses a Human Factors systems framework to explore the service provision of OPAT.

The robustness of the study was enhanced by the timeframe employed within the study, which supported the capturing of both proximal and distal outcomes of OPAT treatment, an important component of the SEIPS 2.0 framework. However, due to the differences between the studies (and the way in which they were reported) the contributions of specific interactions was difficult to quantify. Despite this limitation, the aim of the review was to evaluate the amenability of the service to the SEIPS 2.0 model, which proved successful.

The authors recognize that, in applying the SEIPS framework to published papers, system data is restricted to that which has been reported. A full Human Factors approach would explore 'work as done' within the OPAT system, rather than this 'work as reported.' 'Work as done' is best explored by gathering data from a range of sources, including direct observation, gathering of quantitative data through audit and the gathering of qualitative data to capture the experience of the system stakeholders. This approach will define the future phases of this work, in which the visiting nurse model currently being provided in Malta since October 2016 will be explored using the SEIPS 2.0 framework. The final step will be to map the factors extracted from the triangulated data sources onto the SEIPS 2.0 model and compare the findings with those of this review.

\section{Conclusion}

The systematic review sheds light on the numerous Human Factors aspects inherent in the provision of the OPAT service. Despite the high service success rates extracted from the studies, various aspects of 
the service can be tackled to enhance other measurable outcomes which might have not been considered by institutions such as patient and provider satisfaction.

Despite the robust data identified in this systematic review, there is still a lot of research which needs to be done in terms of deciphering work system factors specific to the various OPAT models of care as well as to delve further into the experiences of patients who are the end users of this system.

Funding: This research did not receive any specific grant from funding agencies in the public, commercial, or not-for-profit sectors

\section{Conflict of Interest or Bias: None}

\section{References}

1. Rahman MH, Tumpa TJ, Ali SM et al. A grey approach to predicting healthcare performance. Measurement 2019; 1(34): 307-325

2. Norris AH, Shrestha NK, Allison GM et al. 2018 Infectious Diseases Society of America Clinical Practice Guideline for the Management of Outpatient Parenteral Antimicrobial Therapy. Clinical Infectious Diseases 2019; 68(1): e1-e35y of the application of a systems approach in UK healthcare the challenges and priorities for implementation. Ergonomics 2018; 61(1):15-25

3. Rucker RW, Harrison GM. Outpatient intravenous medications in the management of Cystic fibrosis. Pediatrics 1974; 54: 358-60.

4. Durojaiye OC, Cartwright K, Ntziora F. Outpatient parenteral antimicrobial therapy (OPAT) in the UK: a cross-sectional survey of acute hospital trusts and health boards. Diagnostic microbiology and infectious disease. 2019 Jan 1;93(1):58-62. 
5. Sriskandarajah S, Hobbs J, Roughead E et al. Safety and effectiveness of 'hospital in the home' and 'outpatient parenteral antimicrobial therapy' in different age groups: A systematic review of observational studies. Int J Clin Pract 2018; e13216.

6. Chapman AL, Seaton RA, Cooper MA et al. Good practice recommendations for outpatient parenteral antimicrobial therapy (OPAT) in adults in the UK: a consensus statement. $J$ Antimicrob Chemother 2012 May;67(5):1053-62.

7. Dul J, Bruder R, Buckle P et al. A strategy for human factors/ergonomics: developing the discipline and profession. Ergonomics 2012;55(4):377-95.

8. Pickup L, Lang A, Atkinson S et al. The dichotomy of the application of a systems approach in UK healthcare the challenges and priorities for implementation. Ergonomics. 2018 Jan $2 ; 61(1): 15-25$

9. Chartered Institute of Ergonomics and Human Factors. Human Factors for Health \& Social Care (White Paper). 2018. Birmingham: CIEHF. Available at https://www.ergonomics.org.uk/Healthcare

10. Hollnagel E, Wears RL, Braithwaite J. From Safety-I to Safety-II: A White Paper. The Resilient Health Care Net: Published simultaneously by the University of Southern Denmark, University of Florida, USA, and Macquarie University, Australia. 2015. Available from: https://www.england.nhs.uk/signuptosafety/wp-content/uploads/sites/16/2015/10/safety-1safety-2-whte-papr.pdf

11. Kohn LT, Corrigan J, Donaldson MS. To err is human: building a safer health system. Washington, DC: National academy press; 2000 Apr.

12. Karsh BT, Holden RJ, Alper SJ et al. A human factors engineering paradigm for patient safetydesigning to support the performance of the health care professional. Quality And Safety in Health care 2006; 15 Suppl 1(Suppl 1):i59-65. 
13. Holden RJ, Carayon P, Gurses AP et al. SEIPS 2.0: A human factors framework for studying and improving the work of healthcare professionals and patients. Ergonomics 2013; 56(11):10.1080/00140139.2013.838643.

14. Karsh BT, Waterson PE and Holden RJ. Crossing levels in systems ergonomics: a framework to support 'mesoergonomic' inquiry. Applied Ergonomics 2014; 45(1):45-54.

15. Carayon P, Hundt AS, Karsh B et al. Work system design for patient safety: the SEIPS model. Quality \& Safety in Health Care 2006; 15 Suppl 1:i50-i58.

16. Moher D, Shamseer L, Clarke M et al. Preferred reporting items for systematic review and meta-analysis protocols (PRISMA-P) 2015 statement. Syst Rev 2015;4:1.

17. Bugeja SJ, Vosper H, Stewart D, Strath A. Human factors approaches to evaluating outpatient parenteral antimicrobial therapy services: a systematic review protocol. 2017. https://www.crd.york.ac.uk/prospero/display_record.phpRecordID=71901

18. The Joanna Briggs Institute. Joanna Briggs Institute Reviewers' Manual: 2014 edition. 2014 http://joannabriggs.org/assets/docs/jbc/operations/dataExtractionForms/JBC_Form_DataE_E xpObs.pdf

19. Centre for Reviews and Dissemination. (2009). Systematic Reviews: CRD's guidance for undertaking systematic reviews in health care, University of York. 2009. https://www.york.ac.uk/media/crd/Systematic_Reviews.pdf

20. Higgins JPT, Green S (editors). Cochrane Handbook for Systematic Reviews of Interventions Version 5.1.0. The Cochrane Collaboration, 2011.

21. Whiting P, Savović J, Higgins JPT et al. ROBIS: A new tool to assess risk of bias in systematic reviews was developed. Journal of Clinical Epidemiology 2016; 69:225-234.

22. Stovold E, Beecher D, Foxlee R et al. Study flow diagrams in Cochrane systematic review updates: an adapted PRISMA flow diagram. Syst Rev 2014 29;3:54.

23. Young JM, Solomon MJ. How to critically appraise an article. Nat Clin Pract Gastroenterol Hepatol 2009 Feb;6(2):82-91. 
24. Bernard L, El-Hajj, Pron B et al. Outpatient parenteral antimicrobial therapy (OPAT) for the treatment of osteomyelitis: evaluation of efficacy, tolerance and cost. J Clin Pharm Ther 2001 Dec;26(6):445-51.

25. Keller SC, Cosgrove SE, Kohut M et al. Hazards from physical attributes of the home environment among patients on outpatient parenteral antimicrobial therapy. American journal of infection control. 2019 Apr 1;47(4):425-30.

26. Keller SC, Cosgrove SE, Arbaje AI, et al. It's Complicated: Patient and Informal Caregiver Performance of Outpatient Parenteral Antimicrobial Therapy-Related Tasks. American Journal of Medical Quality. 2019 Jun 4:1062860619853345.

27. Keller SC, Ciuffetelli D, Bilker W et al. The impact of an Infectious Diseases Transition Service on the Care of Outpatients on Parenteral Antimicrobial Therapy. J Pharm Technol 2013 Oct; 29(5):205-214

28. Gilchrist M, Franklin BD, Patel JP. An outpatient parenteral antibiotic therapy (OPAT) map to identify risks associated with an OPAT service. J Antimicrob Chemother 2008 Jul;62(1):177-83.

29. Perez-Lopez J, Laporte AS, Pardos-Gea J et al. Safety and efficacy of home intravenous antimicrobial infusion therapy in older patients: a comparative study with younger patients. Int J Clin Pract 2008 Aug;62(8):1188-92

30. Gardiol C, Voumard R, Cochet C, de Vallière S. Setting up an outpatient parenteral antimicrobial therapy (OPAT) unit in Switzerland: review of the first 18 months of activity. European Journal of Clinical Microbiology \& Infectious Diseases. 2016 May 1;35(5):839-45.

31. Goodfellow AF, Wai AO, Frighetto L et al. Quality-of-life assessment in an outpatient parenteral antibiotic program. Ann Pharmacother 2002 Dec;36(12):1851-5.

32. Suleyman G, Kenney R, Zervos MJ et al. Safety and efficacy of outpatient parenteral antibiotic therapy in an academic infectious disease clinic. J Clin Pharm Ther 2017 Feb; 42(1):39-43 
33. Al Alawi S, Abdulkarim S, Elhennawy $\mathrm{H}$ et al. Outpatient parenteral antimicrobial therapy with ceftriaxone for acute tonsillopharyngitis: efficacy, patient satisfaction, cost effectiveness, and safety. Infection and Drug Resistance 2015; 8:279-285.

34. Muldoon EG, Switkowski K, Tice A et al. A national survey of infectious disease practitioners on their use of outpatient parenteral antimicrobial therapy (OPAT). Infect Dis 2015 Jan;47(1):39-45.

35. Lane MA, Marschall J, Beekmann SE et al. Outpatient parenteral antimicrobial therapy practices among adult infectious disease physicians. Infect Control Hosp Epidemiol 2014 Jul;35(7):839-44

36. Htin AK, Friedman ND, Hughes A et al. Outpatient parenteral antimicrobial therapy is safe and effective for the treatment of infective endocarditis: a retrospective cohort study. Intern Med J 2013 Jun; 43(6):700-5.

37. Barr DA, Semple L, Seaton RA. Outpatient parenteral antimicrobial therapy (OPAT) in a teaching hospital-based practice: a retrospective cohort study describing experience and evolution over 10 years. Int J Antimicrob Agents 2012 May; 39(5):407-13.

38. Hernandez W, Price C, Knepper B et al. Oral Parenteral Antimicrobial Therapy Administration in a Homeless Population. J Infus Nurs 2016 Mar-Apr;39(2):81-5.

39. Cox AM, Malani PN, Wiseman SW et al. Home intravenous antimicrobial infusion therapy: a viable option in older adults. $J$ Am Geriatr Soc 2007 May;55(5):645-50.

40. Seaton RA, Sharp E, Bezlyak V et al. Factors associated with outcome and duration of therapy in outpatient parenteral antibiotic therapy (OPAT) patients with skin and soft-tissue infections. Int J Antimicrob Agents 2011 Sep;38(3):243-8.

41. Mackintosh CL, White HA, Seaton RA. Outpatient parenteral antibiotic therapy (OPAT) for bone and joint infections: experience from a UK teaching hospital-based service. $J$ Antimicrob Chemother 2011 Feb;66(2):408-15. 
42. Duncan CJ, Barr DA, Ho A et al. Risk factors for failure of outpatient parenteral antibiotic therapy (OPAT) in infective endocarditis. J Antimicrob Chemother 2013 Jul;68(7):1650-4.

43. Williams DN, Baker CA, Kind AC et al. The history and evolution of outpatient parenteral antibiotic therapy (OPAT). Int J Antimicrob Agents 2015 Sep;46(3):307-12.

44. Esposito S, Noviello S, Leone S et al. Outpatient parenteral antibiotic therapy (OPAT) in different countries: a comparison. Int J Antimicrob Agents 2004 Nov; 24(5):473-8

45. Twiddy M, Murray CJ, Mason SJ, Meads D, Wright JM, Mitchell ED, Minton J. A qualitative study of patients' feedback about Outpatient Parenteral Antimicrobial Therapy (OPAT) services in Northern England: implications for service improvement. BMJ open. 2018 Jan 1;8(1):e019099.

46. Berrevoets MA, Oerlemans AJ, Tromp M, Kullberg BJ, ten Oever J, Schouten JA, Hulscher ME. Quality of outpatient parenteral antimicrobial therapy (OPAT) care from the patient's perspective: a qualitative study. BMJ open. 2018 Nov 1;8(11):e024564.

47. Durojaiye OC, Bell H, Andrews D, Ntziora F, Cartwright K. Clinical efficacy, cost analysis and patient acceptability of outpatient parenteral antibiotic therapy (OPAT): a decade of Sheffield (UK) OPAT service. International journal of antimicrobial agents. 2018 Jan $1 ; 51(1): 26-32$.

48. Mirón-Rubio M, González-Ramallo V, Estrada-Cuxart O et al. Intravenous antimicrobial therapy in the hospital-at-home setting: data from the Spanish Outpatient Parenteral Antimicrobial Therapy Registry. Future Microbiol 2016; 11:375-390.

49. Hitchcock J, Jepson AP, Main J et al. Establishment of an outpatient and home parenteral antimicrobial therapy service at a London teaching hospital: a case series. $J$ Antimicrob Chemother 2009 Sep;64(3):630-4.

50. Al Ansari A, Al Alawi S, Al Qahtani M et al. Outpatient parenteral antimicrobial therapy (OPAT) in the kingdom of Bahrain: efficacy, patient satisfaction and cost effectiveness. The open infectious diseases journal 2013; 7:90-95. 
51. Marshall GN, Hays RD. Santa Monica, CA: RAND Corporation; 1994. The Patient Satisfaction Questionnaire Short Form (PSQ-18) p. 7865.

52. Voumard R, Van Neyghem N, Cochet C, et al. Antibiotic stability related to temperature variations in elastomeric pumps used for outpatient parenteral antimicrobial therapy (OPAT). Journal of Antimicrobial Chemotherapy. 2017 May 1;72(5):1462-5.

53. Cervera C, del Río A, García L, et al. Efficacy and safety of outpatient parenteral antibiotic therapy for infective endocarditis: a ten-year prospective study. Enfermedades infecciosas y microbiologia clinica. 2011 Oct 1;29(8):587-92.

54. Durojaiye OC, Kritsotakis EI, Johnston P, et al. Developing a risk prediction model for 30-day unplanned hospitalization in patients receiving outpatient parenteral antimicrobial therapy. Clinical Microbiology and Infection. 2019 July. Clinical Microbiology 2018 Nov 28:25(7): 905.e1-905.e7 
Table 1: Search Strategy

\begin{tabular}{|c|c|}
\hline Core term & Sub-terms \\
\hline \multirow{6}{*}{ Human Factors } & 1.1 human factor* \\
\hline & 1.2 ergonomic* \\
\hline & 1.3 task analysis \\
\hline & 1.4 system* analysis \\
\hline & 1.5 patient safety \\
\hline & 1.6 1.1 OR 1.2 OR 1.3 OR 1.4 OR 1.5 \\
\hline \multirow[t]{8}{*}{ Antibiotics } & 2.1 anti-biotic* \\
\hline & 2.2 antibiotic* \\
\hline & 2.3 anti-bacterial* \\
\hline & 2.4 antibacterial* \\
\hline & 2.5 anti-microbial* \\
\hline & 2.6 antimicrobial* \\
\hline & 2.7 anti-infective* \\
\hline & $\begin{array}{l}2.8 \text { 2.1 OR 2.2 OR 2.3 OR 2.4 OR 2.5 OR } 2.6 \\
\text { OR } 2.7\end{array}$ \\
\hline \multirow[t]{5}{*}{ OPAT setting } & 3.1 ambulatory \\
\hline & 3.2 home \\
\hline & 3.3 outpatient \\
\hline & 3.4 out-patient \\
\hline & 3.5 3.1 OR 3.2 OR 3.3 OR 3.4 \\
\hline \multirow[t]{3}{*}{ Administration } & 4.1 intravenous \\
\hline & 4.2 parenteral \\
\hline & 4.34 .1 OR 4.2 \\
\hline Final Search & 1.6 AND 2.8 AND 3.5 AND 4.3 \\
\hline
\end{tabular}


Table 2: Extracted study characteristics

\begin{tabular}{|c|c|}
\hline Publication Date & $\begin{array}{l}\text { Oldest study: Bernard in } 2001^{24} \\
\text { Most recent: Two studies published by Keller and colleagues in } \\
2019\end{array}$ \\
\hline Study Design & $\begin{array}{l}\text { Retrospective cohort design: most studies except for: } \\
\text { Controlled quasi experimental evaluation: Keller et al., } \\
\text { Expert panel: Gilchrist } \text { et al. }{ }^{28} \text { produced a consensus statement } \\
\text { which was used to map and identify risks associated with OPAT } \\
\text { service delivery } \\
\text { Prospective Investigative Design: used by Perez-Lopez et al. } .^{29} \text {, } \\
\text { Gardiol et al. and Goodfellow et al. } .^{31} \\
\text { Retrospective cross-sectional design: Suleyman et al. }{ }^{32}, \text { Al Alawi } \\
\text { et al. } .^{33} \text {, Muldoon et al. } .^{34} \text { and Lane } \text { et al. } .^{35}\end{array}$ \\
\hline $\begin{array}{l}\text { Population } \\
\text { demographic }\end{array}$ & $\begin{array}{l}\text { Opportunistic sampling: Muldoon et al. and Lane et al. }{ }^{34,35} \\
\text { Purposive sampling: employed for all other studies. }\end{array}$ \\
\hline Data Collection & $\begin{array}{l}\text { Retrospective retrieval of data by using: } \\
\text { Survey: Muldoon } \text { et al. }{ }^{34} \text { and Lane } \text { et al. } .^{35} \\
\text { Patient files, case notes and/or accessing an electronic database. }\end{array}$ \\
\hline Patient Cohorts & $\begin{array}{l}\text { Specific patient cohort: the homeless }{ }^{38} \text {, elderly }{ }^{29,39} \\
\text { Specific disease conditions: skin and soft tissue infections }{ }^{40,33} \text {, bone } \\
\text { and joint infections }{ }^{24,41} \text { or infective endocarditis }{ }^{42,36} \text {. } \\
\text { Broad disease conditions: remaining } 16 \text { studies }\end{array}$ \\
\hline Study timeframe & $\begin{array}{l}\text { A short time frame: } 2 \text { months }^{28}, 1 \text { month }^{35} \\
\text { A long-time frame: } 9 \text { years }^{36,37}, 12 \text { years }^{42}\end{array}$ \\
\hline Study setting & $\begin{array}{l}\text { Australia }^{36} \\
\text { USA }^{25,2632,27,38,39,43,44} \\
\text { Canada }^{31} \\
\text { Europe } \\
\text { East } \text { Asia }^{33,30} \text {. }\end{array}$ \\
\hline OPAT model & $\begin{array}{l}\text { home-visiting professional } 36,29,38,39,37,31,48,28,46,47,25 \\
\text { infusion centre model }{ }^{32,33,50} \\
\text { multiple modes of delivery }{ }^{24,27,34,35,41,44,49,45,30} \\
\text { self-administration } \\
43,44\end{array}$ \\
\hline Sample Size & $\begin{array}{l}\text { Small samples: } 43 \text { patients }{ }^{38}, 82 \text { patients }^{31}, 77 \text { patients }^{42} \\
\text { Large samples: } 4005 \text { patients }^{48}, 963 \text { patients }^{40}\end{array}$ \\
\hline
\end{tabular}



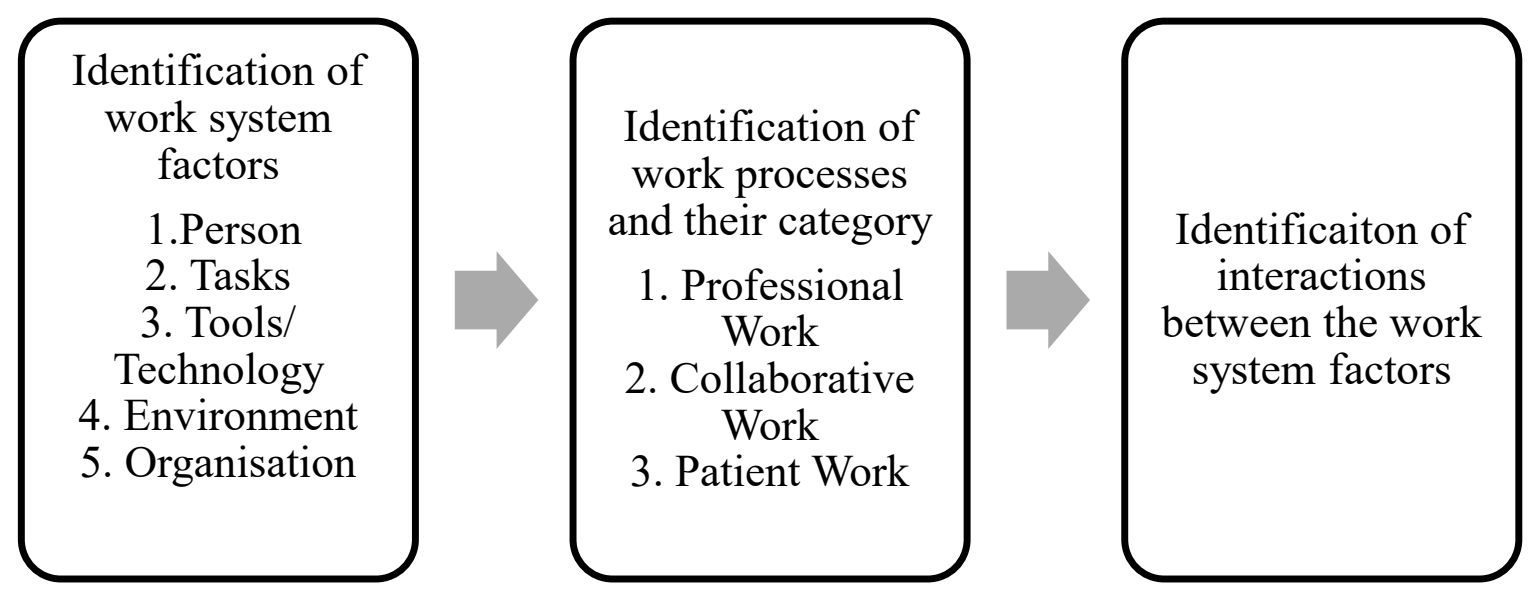

Figure 1 Data Synthesis Strategy 


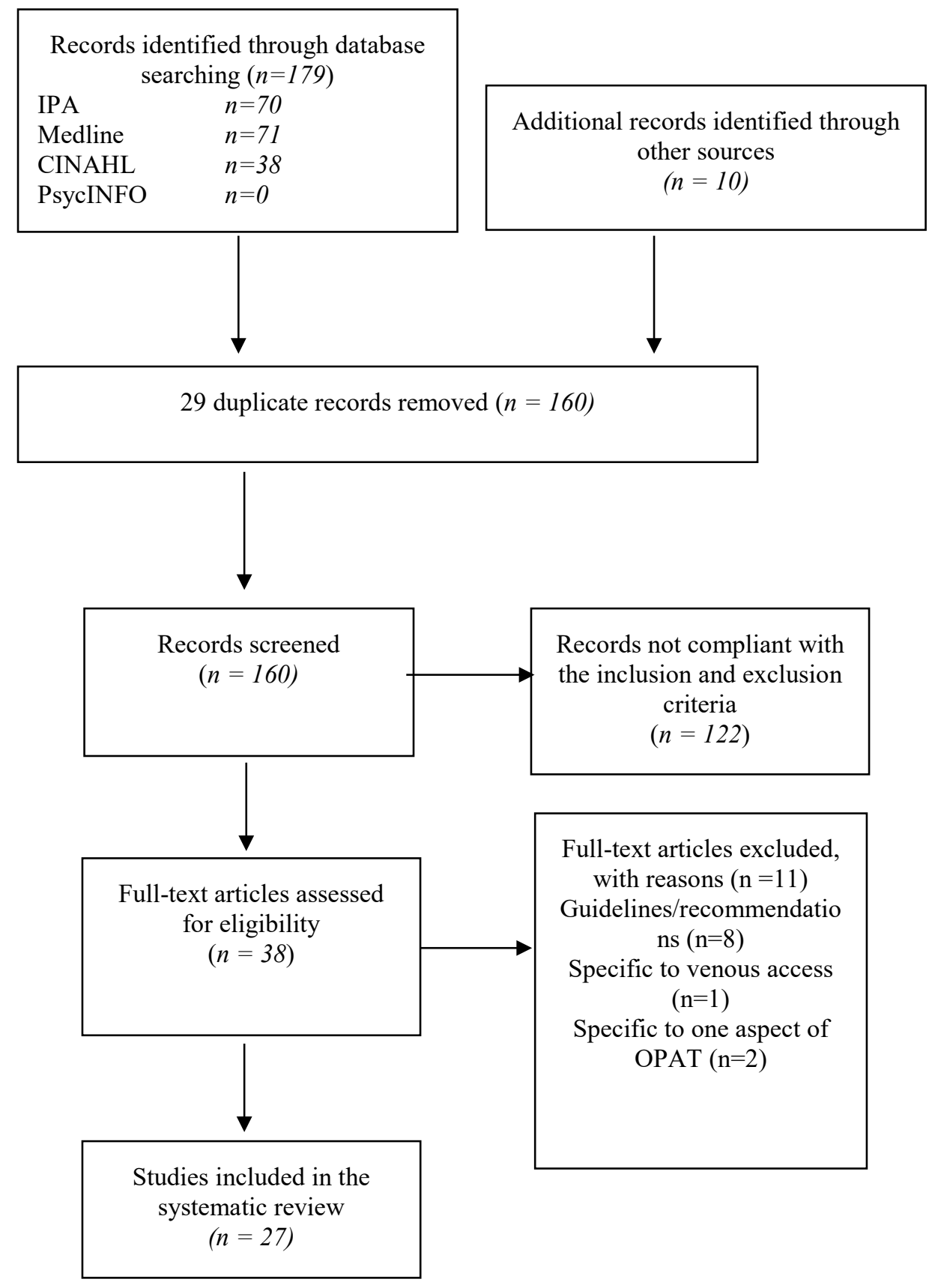

Figure 2 PRISMA Chart describing systematic review search process 


\section{Methodological quality of selected articles}

Did the authors declare that there were no conflicts of interest or bias?

Were failures of the service mentioned?

Did the authors mention facets of the service which can be considered as HF?

Is there a clear statement of findings?

Have ethical issues been taken into consideration?

Were participant characteristics described in detail?

Were the data collected in a way that addressed the research issues?

Was the recruitment strategy appropriately described?

Was the research design appropriate to address the aims of the research?

Was there a clear statement of the aims/ objectives of the research?
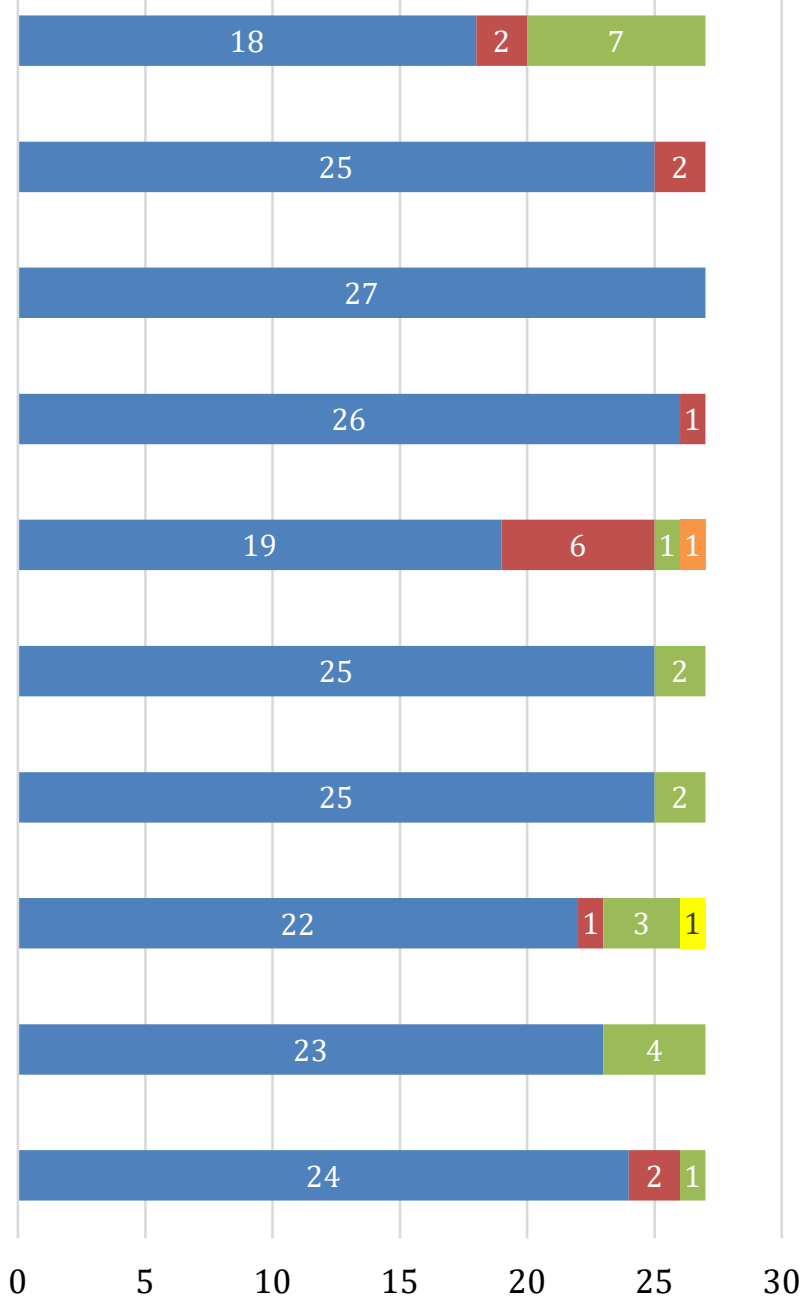

$\square \square \mathrm{N} \backsim \mathrm{P} \backsim \mathrm{U} \backsim \mathrm{N} / \mathrm{A}$

Figure 3 Stacked bar chart describing the methodological quality as captured by the quality assessment tool 
Table 3: Outcomes from the 27 selected studies grouped according to SEIPS 2.0 framework

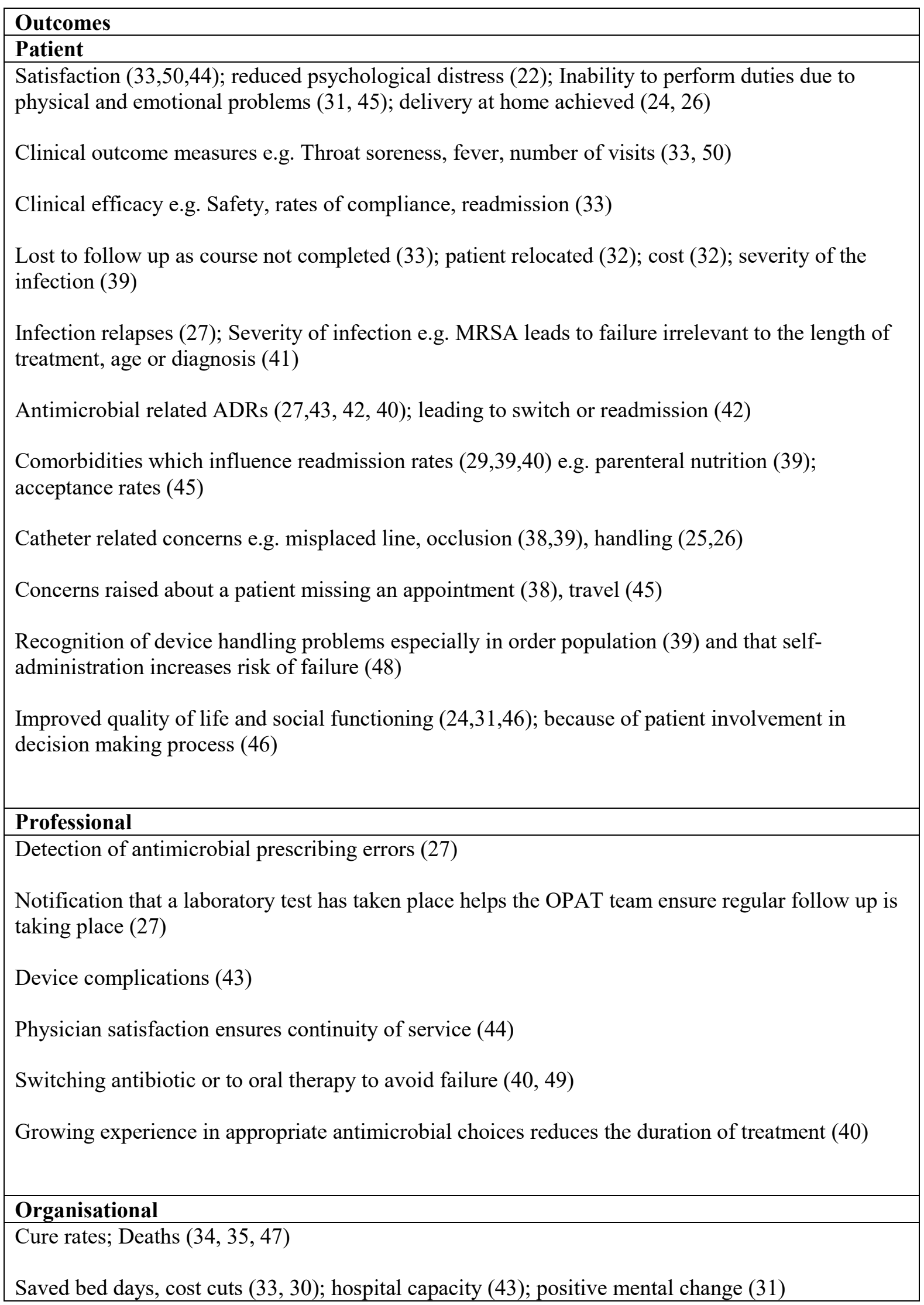


Reduced readmissions $(33,27)$; emergency department visits $(34,48)$

Cost cuts compared to inpatient stays (33)

Process map defining the roles of all those individuals involved in service delivery (27)

Scrutiny of OPAT model effectiveness as determined by outcomes $(24,38)$

Recognition that early monitoring can increase awareness of clinical deterioration and pre-empt readmissions $(24,35)$

Information about healthcare associated infections $(37,46)$ e.g. related to the devices $(37)$

Recognition of the importance of additional care services e.g. diabetes control (41)

Reduced nosocomial infections $(48,49)$ transmission of MRSA, Clostridium difficle associated diarrhoea $(49,45)$

Increased quality of communication between stakeholders (28) assisted with the setup of an OPAT structure (47) 
Table 4: Treatment success and failure rates

\begin{tabular}{|c|c|c|c|c|c|c|c|c|}
\hline \multirow[t]{2}{*}{ Main Author } & \multirow{2}{*}{\multicolumn{2}{|c|}{ Readmission }} & \multirow{2}{*}{\multicolumn{2}{|c|}{ Success }} & \multirow[t]{2}{*}{ Death } & \multicolumn{3}{|c|}{ Complications } \\
\hline & & & & & & \multicolumn{2}{|c|}{$\begin{array}{l}\text { Complication } \\
\text { (most common) }\end{array}$} & Reason \\
\hline Htin et al. 2013 & \multicolumn{2}{|c|}{$3 / 68(4 \%)$} & \multicolumn{2}{|c|}{$64 / 68(94 \%)$} & 0 & \multicolumn{2}{|c|}{$1 / 68(1.4 \%)$} & Line infection \\
\hline $\begin{array}{l}\text { Perez-Lopez et } \\
\text { al. } 2008\end{array}$ & $\begin{array}{l}20 / 9 \\
0 \\
(22 \\
\%) \\
(>70 \\
\text { years } \\
)\end{array}$ & $\begin{array}{l}13 / 55(23 \% \\
)_{(<70 \text { years })}\end{array}$ & \multicolumn{2}{|c|}{$\begin{array}{l}83 / 90(92 \%) \\
\text { (>70years) }\end{array}$} & $0 \%$ & $\begin{array}{l}14 / 90( \\
15 \%) \\
(>70 y e \\
\text { ars })\end{array}$ & \begin{tabular}{|l}
$9 / 55(16$ \\
$\%)$ \\
$(<70 \mathrm{ye}$ \\
ars $)$
\end{tabular} & $\begin{array}{l}\text { Phlebitis, rash, } \\
\text { post antibiotic } \\
\text { diarrhoea }\end{array}$ \\
\hline $\begin{array}{l}\text { Suleyman et al. } \\
2017\end{array}$ & \multicolumn{2}{|c|}{$2 / 122(2 \%)$} & \multicolumn{2}{|c|}{$\begin{array}{l}120 / 122(99 \\
\%)\end{array}$} & $0 \%$ & \multicolumn{2}{|c|}{$\begin{array}{l}16 / 122(13 \%) \\
3 / 102(3 \%)\end{array}$} & $\begin{array}{ll}\text { Adverse drug } \\
\text { event; line } \\
\text { complications }\end{array}$ \\
\hline $\begin{array}{l}\text { Hernandez et al. } \\
2016\end{array}$ & \multicolumn{2}{|c|}{$8 / 43(18.6 \%)$} & \multicolumn{2}{|c|}{$33 / 43(77 \%)$} & $0 \%$ & \multicolumn{2}{|c|}{$7 / 43(16 \%)$} & Social concerns \\
\hline $\begin{array}{l}\text { Williams et al. } \\
2015\end{array}$ & $\begin{array}{l}67 / 1 \\
115 \\
(6 \% \\
\text { ) } \\
\text { anti } \\
\text { bioti } \\
\text { cs } \\
\text { (dat } \\
\text { a } \\
\text { from } \\
957 \\
\text { patie } \\
\text { nts)( } \\
\text { Peri } \\
\text { od } \\
1)\end{array}$ & $\begin{array}{l}3 / 342 \\
(1 \%) \\
\text { antibiotics } \\
\text { (data from } \\
229 \\
\text { patients)( } \\
\text { Period 2) }\end{array}$ & NR & NR & $0 \%$ & $\begin{array}{l}134 / 11 \\
15 \\
(12 \%) \\
\text { antibio } \\
\text { tics; } \\
279 / 11 \\
15 \\
(25 \%) \\
\text { antibio } \\
\text { tics } \\
\text { (data } \\
\text { from } \\
957 \\
\text { patient } \\
\text { s)( } \\
\text { (Perio } \\
\text { d } 1)\end{array}$ & $\begin{array}{l}19 / 342 \\
(6 \%) \\
\text { antibio } \\
\text { tics; } \\
14 / 342 \\
(4 \%) \\
\text { antibio } \\
\text { tics } \\
\text { (data } \\
\text { from } \\
229 \\
\text { patient } \\
\text { s } \\
\text { (Perio } \\
\text { d 2) }\end{array}$ & $\begin{array}{ll}\text { Drug } & \text { related } \\
\text { event; } & \text { venous } \\
\text { access } & \\
\text { complications }\end{array}$ \\
\hline Barr et al. 2012 & \multicolumn{2}{|c|}{$\begin{array}{l}\text { 262/2233(11.7\%) } \\
\text { OPAT episodes }\end{array}$} & \multicolumn{2}{|c|}{$\begin{array}{l}2063 / 2233( \\
92.4 \%) \\
\text { OPAT } \\
\text { episodes }\end{array}$} & $\begin{array}{l}8 / 2233 \\
(0.4 \%) \\
\text { OPAT } \\
\text { episodes }\end{array}$ & \multicolumn{2}{|c|}{$\begin{array}{l}219 / 2233 \\
(9.8 \%) \text { OPAT } \\
\text { episodes }\end{array}$} & $\begin{array}{ll}\begin{array}{l}\text { Adverse } \\
\text { event }\end{array} & \text { drug } \\
\end{array}$ \\
\hline $\begin{array}{l}\text { Duncan et al. } \\
2013\end{array}$ & \multicolumn{2}{|c|}{$\begin{array}{l}21 / 80(26.3 \%) \\
\text { episodes }\end{array}$} & \multicolumn{2}{|c|}{$\begin{array}{l}55 / 80 \\
(68.7 \%) \\
\text { episodes }\end{array}$} & $\begin{array}{l}2 / 80(2.5 \\
\%) \\
\text { episodes }\end{array}$ & \multicolumn{2}{|c|}{$\begin{array}{l}7 / 80(8.7 \%) \\
\text { episodes; } \\
3 / 80(4.1 \%) \\
\text { episodes }\end{array}$} & $\begin{array}{l}\text { Adverse drug } \\
\text { event, other line } \\
\text { complication }\end{array}$ \\
\hline $\begin{array}{l}\text { Miron-Rubio et } \\
\text { al. } 2016\end{array}$ & \multicolumn{2}{|c|}{$\begin{array}{l}328 / 4416(7.4 \%) \\
\text { episodes }\end{array}$} & \multicolumn{2}{|c|}{$\begin{array}{l}4018 / 4416( \\
91 \%) \\
\text { episodes }\end{array}$} & $\begin{array}{l}58 / 4416 \\
(1.3 \%) \\
\text { episodes }\end{array}$ & \multicolumn{2}{|c|}{$\begin{array}{l}241 / 4416 \\
(5.4 \%) \text { episodes }\end{array}$} & $\begin{array}{l}\text { catheter } \\
\text { complications }\end{array}$ \\
\hline $\begin{array}{l}\text { Seaton et al. } \\
2011\end{array}$ & \multicolumn{2}{|c|}{$\begin{array}{l}58 / 963(6 \%) \\
\text { episodes }\end{array}$} & \multicolumn{2}{|c|}{$\begin{array}{l}83 / 9963 \\
(87.1 \%) \\
\text { episodes }\end{array}$} & $\mathrm{NR}$ & \multicolumn{2}{|c|}{$\begin{array}{l}68 / 963(7 \%) \\
\text { episodes }\end{array}$} & $\begin{array}{l}\text { Complication of } \\
\text { infection process, } \\
\text { significant } \\
\text { adverse event }\end{array}$ \\
\hline
\end{tabular}




\begin{tabular}{|l|l|l|l|l|l|}
\hline $\begin{array}{l}\text { Hitchcock et al. } \\
2009\end{array}$ & $\begin{array}{l}23 / 303(7.6 \%) \\
\text { courses }\end{array}$ & $\begin{array}{l}278 / 303(91 . \\
7 \%) \\
\text { episodes }\end{array}$ & NR & $\begin{array}{l}2 / 303(0.7 \%) \\
\text { episodes }\end{array}$ & $\begin{array}{l}\text { Adverse drug } \\
\text { event }\end{array}$ \\
\hline $\begin{array}{l}\text { Gardiol et al. } \\
2016\end{array}$ & $\begin{array}{l}24 / 179(12 \%) \\
\text { episodes }\end{array}$ & $\begin{array}{l}168 / 179 \\
(94 \%) \\
\text { episodes }\end{array}$ & $0 \%$ & $\begin{array}{l}10 / 179(5.5 \%) \\
\text { episodes }\end{array}$ & $\begin{array}{l}\text { Adverse drug } \\
\text { event }\end{array}$ \\
\hline $\begin{array}{l}\text { Durojaiye et al. } \\
2018\end{array}$ & $\begin{array}{l}265 / 3812(7 \%) \\
\text { episodes }\end{array}$ & $\begin{array}{l}3357 / 3812 \\
(88.1 \%) \\
\text { episodes }\end{array}$ & $\begin{array}{l}2 / 3812 \\
(0.1 \%) \\
\text { episodes }\end{array}$ & $\begin{array}{l}265 / 3812(7 \%) \\
\text { episodes }\end{array}$ & $\begin{array}{l}\text { Adverse events, } \\
\text { line related } \\
\text { complications }\end{array}$ \\
\hline
\end{tabular}




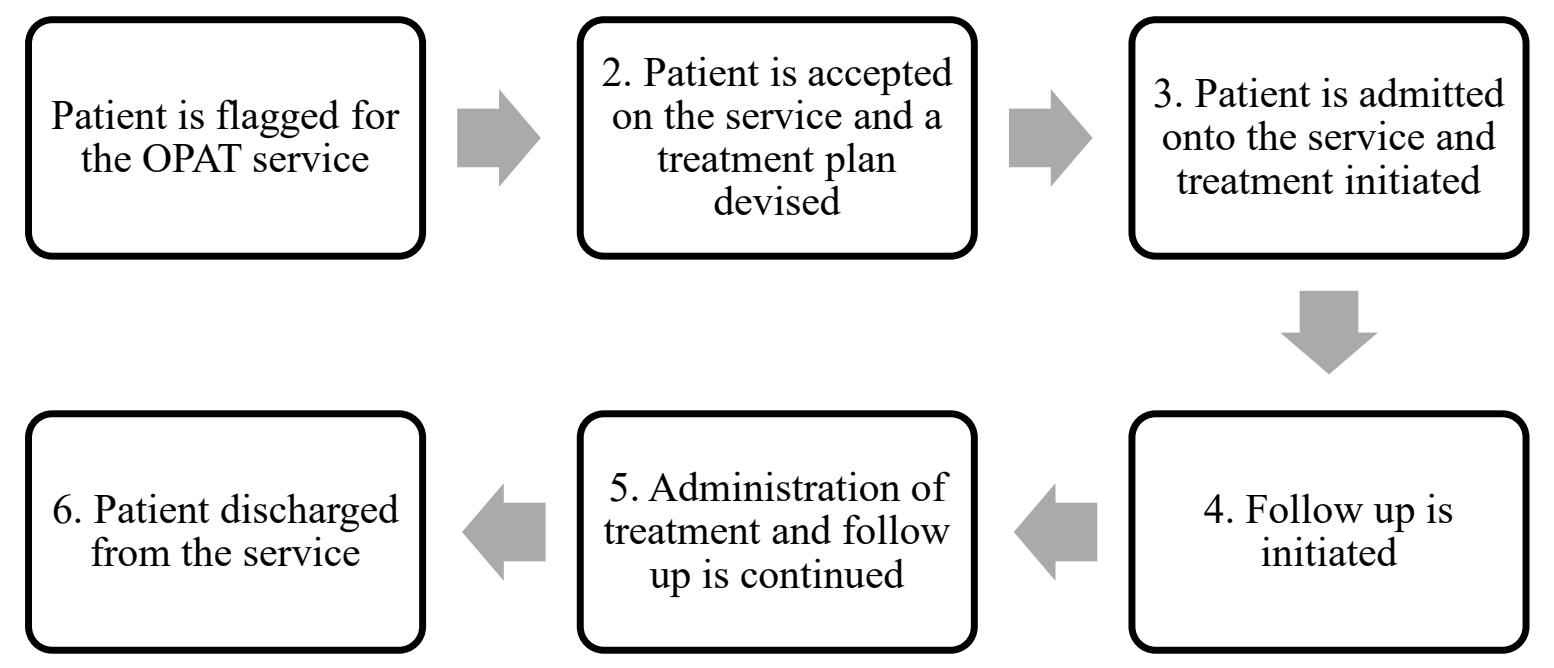

Figure 4 The generic processes involved in rendering an OPAT service 
Table 5 The physical, cognitive and social processes relating to 'professional work' (as described by the SEIPS 2.0 model) pertaining to each phase of the OPAT service

\begin{tabular}{|c|c|c|c|}
\hline Service Phase & Physical & Cognitive & Social \\
\hline $\begin{array}{l}\text { Patient is flagged for } \\
\text { the OPAT service }\end{array}$ & $\begin{array}{l}\text { Assessment of OPAT } \\
\text { workload to evaluate } \\
\text { whether the team can } \\
\text { take on another patient } \\
(47)\end{array}$ & $\begin{array}{l}\text { Selection of the patient } \\
\text { according to the } \\
\text { institution's eligibility } \\
\text { criteria }(40,36,32 \text {, } \\
37) \text {; }\end{array}$ & $\begin{array}{l}\text { Communication with } \\
\text { all stakeholders } \\
\text { involved in rendering } \\
\text { the service }(34,43,46) \text {; } \\
\text { Motivating } \\
\text { professionals to cure } \\
\text { more complex disease } \\
\text { states (37) }\end{array}$ \\
\hline $\begin{array}{l}\text { Patient is accepted on } \\
\text { the service and a } \\
\text { treatment plan } \\
\text { devised }\end{array}$ & $\begin{array}{l}\text { Treating homeless } \\
\text { patients e.g. using a } \\
\text { respite shelter (38) }\end{array}$ & $\begin{array}{l}\text { Teaching patients how } \\
\text { to administer using } \\
\text { aseptic techniques } \\
(37,48,25,26) \text {; } \\
\text { Awareness of new } \\
\text { pharmaceutical } \\
\text { formulas which allow } \\
\text { new administrations } \\
(29)\end{array}$ & $\begin{array}{l}\text { Decreasing the use of } \\
\text { inappropriate therapy } \\
(34,35,32,43) ; \\
\text { Liaising with all } \\
\text { stakeholders to } \\
\text { successfully discharge } \\
\text { patient onto the } \\
\text { service }(34,43) ;\end{array}$ \\
\hline $\begin{array}{l}\text { Patient is admitted } \\
\text { onto the service and } \\
\text { treatment initiated }\end{array}$ & $\begin{array}{l}\text { Administration of } \\
\text { treatment; Use of } \\
\text { different } \\
\text { administration } \\
\text { techniques }(44,48)\end{array}$ & $\begin{array}{l}\text { Improvement of } \\
\text { transitional care } \\
\text { processes e.g. } \\
\text { reducing the errors } \\
\text { that occur during } \\
\text { antimicrobial } \\
\text { prescribing }(27)\end{array}$ & $\begin{array}{l}\text { Provide support to } \\
\text { patients and caregivers } \\
(46)\end{array}$ \\
\hline Follow up is initiated & $\begin{array}{l}\text { Requesting and } \\
\text { charting of laboratory } \\
\text { tests }(24,35)\end{array}$ & $\begin{array}{l}\text { Monitoring and } \\
\text { inferences from } \\
\text { laboratory tests }(24,35 \text {, } \\
26,47)\end{array}$ & $\begin{array}{l}\text { Culture of regular } \\
\text { monitoring set up to } \\
\text { prevent adverse events } \\
(45)\end{array}$ \\
\hline $\begin{array}{l}\text { Administration of } \\
\text { treatment and follow } \\
\text { up is continued }\end{array}$ & $\begin{array}{l}\text { Drawing of blood } \\
\text { samples to be sent to } \\
\text { the laboratory for } \\
\text { testing (26) }\end{array}$ & $\begin{array}{l}\text { Addressing patterns of } \\
\text { previous unsuccessful } \\
\text { patient groups to pre- } \\
\text { empt future } \\
\text { readmissions (42) }\end{array}$ & $\begin{array}{l}\text { Empowering patients } \\
(37,48) ; \text { Working } \\
\text { towards lowering } \\
\text { readmission rates } \\
\text { through better follow } \\
\text { up measures }(27,33 \text {, } \\
47)\end{array}$ \\
\hline $\begin{array}{l}\text { Patient is discharged } \\
\text { from the service }\end{array}$ & $\begin{array}{l}\text { Removal of vascular } \\
\text { access device (26) }\end{array}$ & & $\begin{array}{l}\text { Planning of the } \\
\text { service to generate } \\
\text { higher success rates } \\
\text { and fewer } \\
\text { readmissions }(34,40, \\
36,32,37,30) ; \\
\text { Achieving } \\
\text { professional } \\
\text { satisfaction (44) }\end{array}$ \\
\hline
\end{tabular}


Table 6 The physical, cognitive and social processes relating to 'collaborative work' (as described by the SEIPS 2.0 model) pertaining to each phase of the OPAT service

\begin{tabular}{|c|c|c|c|}
\hline Service Phase & Physical & Cognitive & Social \\
\hline $\begin{array}{l}\text { Patient is flagged for } \\
\text { the OPAT service }\end{array}$ & $\begin{array}{l}\text { Assessment of skill set } \\
\text { and dissemination of } \\
\text { roles and } \\
\text { responsibilities (26) }\end{array}$ & $\begin{array}{l}\text { Knowing } r \text { which } \\
\text { factors cause poor } \\
\text { outcomes e.g. older } \\
\text { age, methicillin- } \\
\text { resistant } \\
\text { Staphylococcus aureus } \\
\text { infection and diabetic } \\
\text { foot infection (41) }\end{array}$ & \\
\hline $\begin{array}{l}\text { Patient is accepted on } \\
\text { the service and a } \\
\text { treatment plan } \\
\text { devised }\end{array}$ & $\begin{array}{l}\text { Taking consent prior to } \\
\text { toxic treatment (34) }\end{array}$ & $\begin{array}{l}\text { Deciding which } \\
\text { administration } \\
\text { techniques to use } \\
\text { depending on } \\
\text { discussions between } \\
\text { professionals and } \\
\text { patients (41); training } \\
\text { vascular access device } \\
\text { management (26) }\end{array}$ & $\begin{array}{l}\text { Recognition that an } \\
\text { appropriate OPAT } \\
\text { structure can establish } \\
\text { a treatment plan with } \\
\text { patient (47) }\end{array}$ \\
\hline $\begin{array}{l}\text { Patient is admitted } \\
\text { onto the service and } \\
\text { treatment initiated }\end{array}$ & $\begin{array}{l}\text { Delivery of } \\
\text { medications by courier } \\
(26)\end{array}$ & $\begin{array}{l}\text { Monitoring of patient } \\
\text { technique by team (26) }\end{array}$ & $\begin{array}{l}\text { Establishing and } \\
\text { maintaining } \\
\text { communication } \\
\text { channels between } \\
\text { OPAT team members } \\
\text { and patients }(28,49 \text {, } \\
26,45)\end{array}$ \\
\hline Follow up is initiated & $\begin{array}{l}\text { Devising a schedule } \\
\text { for withdrawal of } \\
\text { blood samples and } \\
\text { testing (26) }\end{array}$ & & \\
\hline $\begin{array}{l}\text { Administration of } \\
\text { treatment and follow } \\
\text { up is continued }\end{array}$ & $\begin{array}{l}\text { Ensuring patients } \\
\text { attend hospital } \\
\text { appointments(34); } \\
\text { Reporting of adverse } \\
\text { events (35) }\end{array}$ & $\begin{array}{l}\text { Awareness of sterility } \\
\text { procedures during } \\
\text { administrations (26) }\end{array}$ & $\begin{array}{l}\text { Ensuring patients are } \\
\text { taking care of vascular } \\
\text { access device and } \\
\text { coping with daily life } \\
\text { activities (46) }\end{array}$ \\
\hline $\begin{array}{l}\text { Patient is discharged } \\
\text { from the service }\end{array}$ & $\begin{array}{l}\text { Removal of venous } \\
\text { access device }(26)\end{array}$ & & \\
\hline
\end{tabular}


Table 7: The physical, cognitive and social processes relating to 'patient work' (as described by the SEIPS 2.0 model) pertaining to each phase of the OPAT service

\begin{tabular}{|c|c|c|c|}
\hline Service Phase & Physical & Cognitive & Social \\
\hline $\begin{array}{l}\text { Patient is flagged for } \\
\text { the OPAT service }\end{array}$ & $\begin{array}{l}\text { Assessment of patient } \\
\text { comorbidities in } \\
\text { managing at home } \\
(45)\end{array}$ & 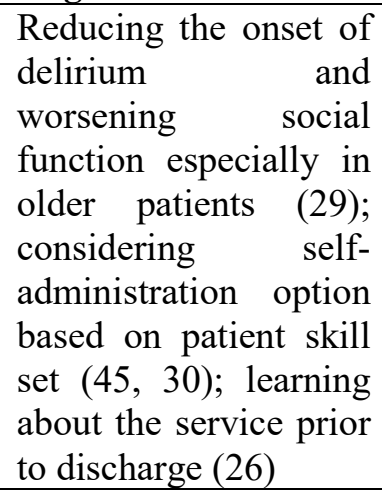 & $\begin{array}{l}\text { Consideration of the } \\
\text { impact of home visits } \\
\text { on the patient's } \\
\text { freedom (46) }\end{array}$ \\
\hline $\begin{array}{l}\text { Patient is accepted on } \\
\text { the service and a } \\
\text { treatment plan } \\
\text { devised }\end{array}$ & \begin{tabular}{lr}
\multicolumn{2}{l}{ Ensuring adherence to } \\
prescribed \\
especially $r$ therapy \\
intravenous \\
abusers (43)
\end{tabular} & $\begin{array}{l}\text { Recognising that } \\
\text { offering the option of } \\
\text { being treated at home } \\
\text { may help in terms of } \\
\text { patient responsiveness } \\
\text { and morale }(38,39)\end{array}$ & $\begin{array}{l}\text { Maintaining a home } \\
\text { environment ro } \\
\text { include: supporting } \\
\text { maintenance of } \\
\text { familiar dietary habits, } \\
\text { continuous family } \\
\text { support and the ability } \\
\text { to move about (29) }\end{array}$ \\
\hline $\begin{array}{l}\text { Patient is admitted } \\
\text { onto the service and } \\
\text { treatment initiated }\end{array}$ & $\begin{array}{l}\text { Asking for the } \\
\text { assistance of family } \\
\text { members with } \\
\text { administration } \\
\text { techniques and devices } \\
\text { (39); ensuring patients } \\
\text { are aware how to tackle } \\
\text { home hazards (25) }\end{array}$ & $\begin{array}{l}\text { Improving } \\
\text { psychological distress } \\
\text { and social functioning, } \\
\text { due to emotional } \\
\text { problems }(31,33) \\
\text { wellbeing }(50,43)\end{array}$ & $\begin{array}{l}\text { Empowering a culture } \\
\text { that promotes more } \\
\text { admissions onto the } \\
\text { OPAT service }(33,49)\end{array}$ \\
\hline Follow up is initiated & $\begin{array}{l}\text { Ensuring that patients } \\
\text { do not fail to show up } \\
\text { at follow up } \\
\text { appointments (43); } \\
\text { ensuring travel } \\
\text { arrangements are done } \\
\text { for any appointments } \\
\text { (45) }\end{array}$ & & \\
\hline $\begin{array}{l}\text { Administration of } \\
\text { treatment and follow } \\
\text { up is continued }\end{array}$ & $\begin{array}{l}\text { Seeking urgent care } \\
\text { services especially a } \\
\text { geriatric cohort (39); } \\
\text { ensuring the vascular } \\
\text { device is not misused } \\
\text { (43); calling the } \\
\text { infectious diseases } \\
\text { pharmacist or } \\
\text { physicians with } \\
\text { questions especially } \\
\text { older patients (39); } \\
\text { ensuring the vascular }\end{array}$ & $\begin{array}{l}\text { Ensuring the patients } \\
\text { are correctly } \\
\text { administering } \\
\text { medications for the } \\
\text { given amount of time } \\
\text { (26) }\end{array}$ & $\begin{array}{l}\text { Maintaining a normal } \\
\text { daily routine }(37,44) \text {; } \\
\text { factoring in the support } \\
\text { required from relatives } \\
\text { (46); avoiding harm } \\
\text { whilst performing } \\
\text { activities of daily } \\
\text { living (26) }\end{array}$ \\
\hline
\end{tabular}




\begin{tabular}{|l|l|l|l|}
\hline & $\begin{array}{l}\text { device is kept safe } \\
\text { from home hazards } \\
(25)\end{array}$ & & \\
\hline $\begin{array}{l}\text { Patient is discharged } \\
\text { from the service }\end{array}$ & & & $\begin{array}{l}\text { Maintaining a normal } \\
\text { daily routine }(37,44)\end{array}$ \\
\hline
\end{tabular}


Table 8: Extracted work system factors from the selected articles

\section{Work System Factors}

Tools/Technology

Eligibility criteria specific to the ear, nose and throat department (33)

Choice of drug based on profile/clinical condition/penicillin resistance (33) e.g. Ceftriaxone Consideration of various routes of administration (33)

Improved medical devices and technologies $(37,43)$ elastomeric pumps $(48,30)$

Adaptability of the service allows more intravenous medicines to be administered (37)

New treatment options allow more conditions to be treated (37)

Patient/carer capability to self-administer (30) increases range of drugs and frequencies (48)

\section{Tasks}

Written instructions to go to the emergency department if adverse event occurs (50)

Eligibility criteria (33) Patient Selection $(33,36,29,32,35)$

Assistance by family/carer with medication administration (29); travelling to avoid delays in administration (25); understanding information (46)

Monitoring (24) daily (33) by the infectious diseases' physician (18) of the patients' clinical assessment and laboratory parameters $(50,34,43,35,37)$

Complexity categorisation depending if they are short or long treatments (50)

Patient follow up $(34,41,28,45)$

Treatment selection with respect to cost, efficacy, frequency of administration, comorbidities etc. (43)

Education for patients/carers for performing infusions, importance of sterility $(36,39,45)$

Patients/carer capability in performing infusions, importance of sterility (39) daily activities with a indwelling line (25)

Travelling to appointments (45)

Person 
Eligibility e.g. Comorbidities (diabetes mellitus, hypertension, obesity, chronic obstructive pulmonary disease, asthma) (33) cardiac, renal (42)

Eligibility based on specific clinical guidelines $(33,50)$

Eligibility e.g. Inability to swallow (33)

Willingness to deal with multiple conditions $(33,50)$; willingness to accept service if provided with more information about treatment given (45)

Knowledge, skills and ability to perform before the patient is discharged on the service $(27,29$, 45)

Patient's age (29)

Patient willingness to be offered service $(44,46,30)$, hesitation to leave inpatient setting $(31,45)$

Emotional impact of having an indwelling device $(45,46)$

\section{Organisation}

Referrals from medical, surgical and emergency departments $(48,50)$; avoidance of delayed transition from hospital to residence (46)

Multidisciplinary OPAT team with the necessary training and skills $(50,35,40,42,47)$

Education for referring institutions to avoid their refusing eligible patients (49)

Provision of formal guidelines (38)

Channels of communication (35) involving infectious diseases specialists $(34,46)$ Electronic databases (43)

Role of the OPAT director to decide which measure to use to monitor measure outcomes (34)

Move towards community-based model to decrease bed occupancy (30)

Involvement of infectious disease physicians prior to discharge (35)

Lack of a reporting system for errors (35), lack of an in house database (47)

Other medical services e.g. diabetes control, wound management, nutritional support (41)

Flexibility of provider avoids limiting patients' daily activities $(46,47)$

\section{External Environment}

Guidelines e.g. centres for disease control and prevention guidelines (33)

Referral from private entity to maintain treatment (33), referral from a general practitioner (50) 
OPAT Clinic (33)

Geographical distribution of patients (35)

Influence of this on administration times (49)

Versatility of the service allows more intravenous medicines to be administered (37)

Patient or carer model versus infusion model (44)

Home environment that guarantees personal safety (45) and that of the access device (25)

Hospital environment supporting transmission of Clostridium difficle and MRSA (45)

Avoidance of extreme temperatures, dirt, pets and measures to declutter residence (25) 
Table 9: Key interactions of the most frequently extracted work system factors

\begin{tabular}{|c|c|c|}
\hline Work System Factors & Factor Descriptors & Key interactions \\
\hline \multirow[t]{2}{*}{$\begin{array}{l}\text { Tools/tech Factors- T1, } \\
\text { T2 }\end{array}$} & $\begin{array}{l}\text { T1 Design and efficiency of medical devices and } \\
\text { technologies used to administer treatment }\end{array}$ & $\begin{array}{l}\text { Tas } 4, \mathrm{P} 2, \mathrm{P} 3 \\
\text { EE2 }\end{array}$ \\
\hline & $\begin{array}{l}\text { T2 Accessibility of medical devices and technologies } \\
\text { to perform laboratory testing from blood samples }\end{array}$ & Tas2, Tas3, P3 \\
\hline \multirow[t]{4}{*}{$\begin{array}{l}\text { Tasks Factors- Tas } 1 \text {, } \\
\text { Tas2, Tas3, Tas } 4\end{array}$} & $\begin{array}{l}\text { Tas } 1 \text { The need to ensure that patients are selected in } \\
\text { line with international OPAT guidelines }\end{array}$ & $\begin{array}{l}\text { P1, P3, EE1, O1, } \\
\text { P2, O2, IE1 }\end{array}$ \\
\hline & $\begin{array}{l}\text { Tas2 The requirement to ensure regular patient } \\
\text { laboratory monitoring and clinical evaluation }\end{array}$ & Tas3, P2 \\
\hline & $\begin{array}{l}\text { Tas3 The importance of carrying out regular patient } \\
\text { follow-up and re-evaluation by healthcare } \\
\text { professionals to assess patient's prognosis }\end{array}$ & $\begin{array}{l}\mathrm{P} 2, \mathrm{O} 2, \mathrm{IE} 1, \mathrm{P} 3 \\
\mathrm{O} 3\end{array}$ \\
\hline & $\begin{array}{l}\text { Tas4 } 4 \text { The need to educate patient/carer about the } \\
\text { service and their involvement with the professionals } \\
\text { offering the service }\end{array}$ & $\mathrm{P} 2, \mathrm{P} 3, \mathrm{O} 2$ \\
\hline \multirow[t]{3}{*}{$\begin{array}{l}\text { Person(s) Factors- P1, } \\
\text { P2, P3 }\end{array}$} & $\begin{array}{l}\text { P1 Patient eligibility due to comorbidities such as } \\
\text { diabetes mellitus, hypertension, obesity, chronic } \\
\text { obstructive pulmonary disease, asthma, cardiac, renal }\end{array}$ & \\
\hline & $\begin{array}{l}\text { P2 Healthcare professionals' knowledge, skills and } \\
\text { ability to provide OPAT service }\end{array}$ & $\mathrm{O} 2, \mathrm{O} 3, \mathrm{EE}, \mathrm{EE} 2$ \\
\hline & $\begin{array}{l}\text { P3 Patient willingness to be offered service and leave } \\
\text { inpatient setting }\end{array}$ & \\
\hline \multirow[t]{3}{*}{$\begin{array}{l}\text { Organisation Factors- } \\
\mathrm{O} 1, \mathrm{O} 2, \mathrm{O} 3\end{array}$} & $\begin{array}{l}\text { O1 The organisational need to ensure patients are } \\
\text { discharged from hospital onto the OPAT service }\end{array}$ & $\mathrm{O} 2, \mathrm{P} 1, \mathrm{O} 3$ \\
\hline & $\begin{array}{l}\text { O2 Setup and maintenance of an appropriately } \\
\text { trained and skilled multidisciplinary OPAT team }\end{array}$ & EE1 \\
\hline & $\begin{array}{l}\text { O3 Existence of standard channels of communication } \\
\text { between healthcare professionals to ensure seamless } \\
\text { care }\end{array}$ & \\
\hline \multirow[t]{2}{*}{ External Factors- EE1 } & $\begin{array}{l}\text { EE1 Referral from private institution to maintain } \\
\text { treatment e.g. GP clinic }\end{array}$ & \\
\hline & $\begin{array}{l}\text { EE2 Geographical distribution of patients influences } \\
\text { administration times }\end{array}$ & \\
\hline Internal Factors- IE1 & $\begin{array}{l}\text { IE1 Physical environment depends on the model of } \\
\text { care (i.e. infusion centre, patient residence etc.) }\end{array}$ & \\
\hline
\end{tabular}

